\title{
A UNIVERSIDADE LATINO-AMERICANA: SUAS POSSIBILIDADES E RESPONSABILIDADES.
}

\section{(Contribuição brasileira ao estudo do problema) $\left(^{\star}\right)$.}

Não é fácil para um brasileiro que não está suficientemente informado sôbre as origens, a evolução e a situação da Universidade hispano-americana, examinar o complexo problema que a instituição universitária apresenta nesta parte do nosso continente. E' que, como justamente escreve Jacques Lambert, as duas metades da América do Sul, "são dois mundos de costas um para o outro, e entre os quais o intercâmbio de pessoas e, sobretudo, de mercadorias, depois de ter sido impossível durante longo tempo, é ainda hoje difícil" (1). A América do Sul foi ontem, e continua a ser hoje, apesar da aviação, terra de "isolamento", e os nossos povos, mesmo os mais próximos, os mais ligados pela precariedade dos nossos transportes, são, em grande parte, estranhos uns aos outros.

Assim, êste louvável empreendimento do Conselho Interuniversitário Regional, em que altamente colaboram a Universidade da República do Uruguai, a Universidade do Chile e a Universidade de Buenos Aires, como a iniciativa de outras reuniões latino-americanas que se têm realizado, são de largo alcance e de grande proveito para estabelecer, entre nós, contactos que se revelam cada vez mais necessários para o conhecimento dos nossos problemas universitários e de cultura - daqueles que apresentam semelhanças, e também dos que são dissemelhantes - conhecimento êste que se faz urgente

\footnotetext{
(*). - Súmula das palestras realizadas pelo Autor na Universidade de Montevidéu, no III Curso Internacional de Verăo, de 9 a 15 de fevereiro de 1960, curso organizado pelo Conselho Inter-universitário Regional (CIR), patrocinado pelas Universidades da República do Úruguai, Buenos Aires e do Chile. O Autor - apresenta nestas palestras apenas algumas notas que constituem uma contribuição brasileira ao estudo do problema. Aproveita também para apresentar ao CIR. e à Mesa Executiva dos cursos, assim como a todos os amigos uruguaios, os seus agradecimentos pelas aten: çōes que lhe foram dispensadas.

(1). - Jacques Lambert, Os Dois Brasis, ed. do Centro Brasileiro de Pesquișas Educacionais, (Ministério da Educação e Cultura), Rió de Janeiro, 1959, p. 16.
} 
para uma exata e mais clara compreensão do nosso destino comum.

Esta parte do nosso continente adquire, desde a primeira guerra mundial, cada vez maior importância em face da realide internacional.

"O rápido desenvolvimento da indústria delineou mais claramente o futuro econômico que territórios imensos, ricos em matérias-primas, prometem a certos países sul-americanos, e o decréscimo da mortalidade, em face de uma natalidade que se mantém excepcionalmente alta, faz do conjunto dos países ibero-americanos, a zona de crescimento demográfico mais rápido do mundo". Enfim - diz ainda o professor da Universidade de Lyon, Jacques Lambert: "antes mesmo que èssas perspectivas de poderio econômico e demográfico se tenham plenamente convertido em realidade, a conjectura internacional criou para os povos da América Ibérica uma influência política com que, doravante, terão de contar as nações mais poderosas" (2) .

No momento, pois, em que surgem para uma nova fase da história universal, a Ásia e a Africa, esta parte do nosso Continente adquire grande importância e um novo sentido.

"A América - dizia Lucien Fèbvre, em 1954, nas Rencontres Internationales de Génève - a América mudou de lugar, e bruscamente, nestes últimos anos. Ontem, ela era ainda, apenas, a orla ocidental do Atlântico. Agora, ela tende a tornar-se o eixo central de quatro mundos cheios de turbulência e de futuro, de quatro mundos oceânicos" (3) .

Este Novo Mundo e a Europa "constituem talvez o mais dramático problema da história das civilizações e da civilização que se apresenta, não só diante de nós, observa ainda Lucien Fèbvre, como diante dos americanos mas, também perante os homens que, neste momento, forjam um mundo no Pacífico, perante os asiáticos e os africanos. Este problema interessa a tôda a humanidade que hoje já não é apenas uma palavra de sonhador, de utopista, de simples especulador intelectual mas, ao contrário, uma palavra que começou há pouco a afirmar-se como uma realidade" (4).

Mundo que se constrói graças à solidariedade dos grupos que o formam, graças às influências que êles exercem entre

\footnotetext{
(2). - Jacques Lambert, ob. cit., p. 15.

(3). - Lucien Febvre, Les Lumières de Clio, in "Le Nouveau Monde et L'Europe", Baconnière ed., Neuchátel, 1954, p. 26.

(4). - Lucien Febvre, art. cit., in ob. cit., pp. 11-12.
} 
si e que lhes traça uma perspectiva comum; e que, à medida que mais clara e distinta se faz a consciência dos problemas enfrentados, se apresenta mais promissora. Todavia, o problema da América não deve ser considerado apenas no seu aspecto continental, mas, em virtude de suas origens e das próprias condições do mundo moderno, como um problema de história universal. O interêsse, pois, que hoje desperta o problema da América, desmente as palavras de Ortega y Gasset quando afirmava, que a "América ainda não havia começado sua história universal" (5).

Esta história, ao contrário, começou há muito. Porção integrante desde o século XVI de um mundo novo, responsável. em grande parte pelas modificações que se operaram nas atitudes, intelectual e moral, da Europa, a partir de então, a América já se encontra na problemática do mundo civilizado na noção revolucionária do Bom Selvagem, que tem sua origem nas reflexões nascidas dos descobrimentos de novas terras, no aparecimento de formas novas de vida. Ao mesmo tempo que se iniciava a crítica e a renovação das idéias morais na cultura ocidental, como o indica o livro de Montaigne, homens das mais variadas proveniências, aqui vieram construir - trazendo-nos o seu sistema religioso econômico e político - a sua civilização. Mas uma experiência histórica, de caráter novo, aqui também se iniciava e um novo estilo de vida era criado.

Observa justamente o Prof. Herbert Schneider, que "uma vez desembarcadas nas costas americanas, as idéias passam por um curioso e estranho destino. Circunstâncias servem automàticamente de campo de prova para velhas idéias: algumas dessas idéias alcançam nova significação; outras, logo se perdem" (6) .

Daí a razão de apresentar a história das idéias tão grande importância para a América, pois, graças a ela é possivel verificar - e talvez determinar - "sua generalidade, sua aplicação às atividades humanas e sua flexibilidade cultural" (7).

A chamada América Latina, tanto ou talvez mais que a Saxônia, representa assim, um dos mais variados e curiosos laboratórios - se assim podemos dizer - de novas interpretações de idéias e, dentre elas, a de Universidade.

(5). - Ortega y Gasset, Obras Completas (3a. ed.), t. II, p. 727.

(6). - Herbert W. Schnelder, La Bmigracion de Ideas hacla America, in "Fllosofia y Letras", n.0 38 , p. 411 .'

(7). - Herbert W. Schnelder, tbidem. 
Se, pois, tudo concorre para nos dar uma influência política com que devem contar as nações poderosas; se nesse mundo em transformação em que vivemos, novas são as perspectivas que se nos apresentam, que sentido deve ter a Universidade em nossos países? E se ela é, efetivamente, criadora de cultura - qual a sua responsabilidade e quais as suas possibilidades na América Latina na atual conjuntura histórica?

Não sei até que ponto será perfeitamente exata, - mas parece-me que o é - a afirmação de German Arciniegas quando diz em seu livro - Este Pueblo de America que: "el siglo XVI es el siglo en que el común realiza la más prodigiosa de sus hazañas, teniendo por escenario al Nuevo Mundo" (8). "Los reyes, la nobreza, la aristocracia, las altas jerarquias eclesiasticas, - diz o mesmo autor - se quedaban en Europa esperando noticias y seguros de recoger el fruto de la empresa. Quienes desportillan sus filas en el nuevo mundo son los de la plebe: frailes escuálidos, vagabundos, salidos de la taberna o de la carcel, soldados sin titulos" (9).

Entre as classes superiores da Europa, que amoleciam entregues a um "humanismo de galanteio e os homens audazes que vão pedir à fortuna dos mares uma vida nova", escreve Hernâni Cidade, existe um enorme abismo. E' o que vemos, por exemplo - eco da revolução econômica pela qual Portugal passou na época dos descobrimentos - nos versos que Luís da Silveira mandava aos seus amigos da Côrte:

$$
\begin{aligned}
& \text { Vivei bem - aventurados } \\
& \text { Que a fortuna aparelhada } \\
& \text { Tendes já; } \\
& \text { Nós outros somos chamados } \\
& \text { De uns fados em outros fados } \\
& \text { Sem saber o que será (10). }
\end{aligned}
$$

O mesmo diria Ercilla na Araucana:

"Nos las damas, amor, no gentilezas mas el valor, los hechos, las proezas".

(8). - German Arciniegas, Este Pueblo de America, Fondo de Cultura, México, 1945, p. 32.

(9). - German Arciniegas, tbidem.

(10). - Apud H. Cldade; Lị̧oes sôbre a cultura e a Literatura Portuguêsas, voḷ. I, Colmbra ed. Coimbra, 1933, pp. 63764. 
Certo que foi o povo (11), foi o homem humilde mas ambicioso da agitada e confusa Renascença, que lançou na América os alicerces de uma nova forma da civilização européia; foi a gente do povo que plasmou a nossa sociedade, da qual derivará, com variadas vicissitudes, a nossa experiência ou o estilo de nossa vida, como mais tarde seria a aluvião das correntes imigratórias que, confirmando o sentido da experiência passada, dar-lhe-ia moderna amplitude.

"Se ha dicho hasta la saciedad - escreve Picón Salas que es la busca del oro el movil principal de la conquista española, en lo que no diferia, tampoco, de qualquiera otra conquista hecha por los demás paises europeos. Muchos siglos antes que Marx, en su jocunda lengua plebeyota y españolisima habia dicho el Arcipreste de Hita que la primera preocupación del hombre es aver mantenencia"... A que assombrarnos de que esa masa de pecheros, de pequeños hidalgos enpobrecidos, de bastardos sin herancia que formaban el aluvión conquistador, anhelen forjar-se sus insulas de metales preciosos?" (12).

Graças ao trabalho de todos êsses homens que lutaram por haver mantenencia, surgiram as nossas nações que ora tomam, com mais nitidez, consciência de sua condição e de seu porvir. E a Universidade, há de ser em face dêsse trabalho - pois de outro modo estaria destinada ao mais lamentável e rídiculo dos fracassos - precisamente a modalidade mais clara dessa consciência.

Assim, aquêles que se lançaram à aventura da conquista do Orbe Novo, espanhóis e portuguêses, os que moldaram os fundamentos de nossa sociedade e de nossa cultura - êsses aventureiros eram solicitados pelos valores de duas épocas e de duas mentalidades: os da declinante Idade Média, ainda influente sob muitos aspectos e os da Renascença, já marcada-

(11). - Sôbre o homem do povo, o pobre, escreveu Juan del Valle Caviedes, poeta do século XVII, que corresponderia, no Perú, ao nosso Gregório de Matos, êstes interessantes versos:

"El pobre es tonto se calla;

Y si habla es un majadero;

Si sabe, es un hablador;

$Y$ si afable, es embustero.

Si es cortés, intrometido;

Si trabaja, es codicioso,

$y$ por el contrario, extremo

Cuando no sufre, soberbio,

Cobarde, quando es humilde;

un perdido, si descansa,

Miren si son privilegios!

apud, Manuel Bandelra, Literatura Hispano-Americana, 2a. ed. Edit. Fundo de Cultura, Rio de Janeiro, 1960, p. 66.

(12). - Mariano Piçón-Salas, De la Conquista a la Independencia (3a. ed.). Fondo de Cultura, México, 1958, p. 45. 
mente, digamos assim, "burgueses", correspondentes a outras e poderosas tendências do conhecimento e da ação.

Se a Idade Média foi tanto no social como no político, aquela rígida hierarquia, pirâmide de estalões e de valores, pirâmide que começa a ruir quando entra a atuar o regime da livre concorrência sob o império da lei natural (13), não sei se será perfeitamente exata a afirmação de Alfred von Martin quando diz que Deus e o Sangue, os antigos poderes, então são destronados.

O desprestígio do Sangue, da aristocracia, já se vinha processando desde o século XIV, na Península Ibérica. A vitória de Atoleiros, em abril de 1334, já marcava a anulação da Cavalaria e êste acontecimento foi, para Portugal, como diz Antônio Sérgio, a "vitória da classe que deveria inspirar os descobrimentos marítimos" (14), isto é, da burguesia. Também nas Côrtes de Toledo de 1480, os Reis Católicos excluiram os nobres do Conselho de Castela e substituiram-nos por juristas.

"Dêste modo, escrevia Fernando de los Rios, o Conselho, antes composto de chefes militares e de nobres, adquiriu um caráter civil e burguês, ativo e juvenil" (15).

Não se pode dizer, pois, de modo peremptório, como o faz von Martin, em sua Sociologia del Renacimiento, que o mesmo se deu em relação a Deus ou talvez, mais exatamente, à Fé ou à Igreja.

Nos descobrimentos marítimos e na conquista irmanamse, curiosamente, "a fé e o império".

Sílvio Zavala nos conta que "es notoria la riqueza de los documentos relativos a la conquista española de America, entre los cuales se pueden distinguir los religiosos, los oficiales y los de simples particulares, todos de indudable valor para conocer la conciencia de la colonización". E acrescenta: "Si atendemos a los terminos empleados en ellos, observaremos que el interes nacional, predominante en empresas mas modernas, no excluye entonces el plantamiento, enraizado en la Edad Media, que contempla el progreso de la Cristandad a costa de los pueblos gentiles o infieles" (16).

(13). - Alfred von Martin, Sociologia del Renascimiento, Fondo de Cultura, México, 1946, p. 17.

(14). - Antônio Sérgio de Sousa, História de Portugal, Labor ed. Barcelona, 1929, p. 51 .

(15). - Fernando de los Rios, Religion y Estado en la Espafa del siglo XVI, Fondo de Cultura, México, 1957, p. 136.

(16). - Silvio Zavala, La Filosofia de la Conquista, Fondo de Cultura, México, 1947, p. 24 . 
Êsse interêsse na dilatação da fé é também um dos motivos da expansão e da conquista européias.

No que concerne ao Brasil e à sua colonização, basta que lhes repita o que escrevia o grande historiador Capistrano de Abreu: "uma história dos jesuítas é obra urgente; enquanto não a possuirmos será presunçoso quem quiser escrever a do Brasil" (17) - quer dizer: sem a compreensão do que foi a conquista dos jesuítas, bem difícil é compreender o que foi a história de meu país.

- " AAmérica se abria às emprêsas do espírito aventureiro dos europeus, ao mesmo tempo que Inácio e seus companheiros se dedicavam, com voto especial, à grande obra das missões estrangeiras. Era impossível que esta terra - escrevia o Pe. Madureira - revelada ao gênio europeu, não se tornasse para os jesuítas um vasto teatro de fadigas apostólicas. A Companhia tem tôda a razão de dizer com o Padre Nóbrega: Esta terra é nossa emprêsa; O Brasil é nosso; mas também o Brasil pode dizer: "o jesuíta é nosso, pela dedicação e afeto com que, desde sua chegada, êle se colocou ao lado dos brasis, na infância de sua vida cívica, como afetuoso e devotado pedagogo" (18).

E' fora de dúvida que, em grande parte, o Brasil foi emprêsa dos companheiros de Santo Inácio, embora muito exista de criticável nesse empreendimento...

De minha parte creio que o espírito da cultura jesuítica marcou fortemente a inteligência de meu país. Suspeito - mas aí cumpre apenas que eu indague - se a mesma coisa não teria acontecido com os demais países desta parte do nosso continente?...

Se a conquista e o processo da colonização de nosso continente se tornam, cada dia mais, um problema de história da economia mundial, um aspecto das variadas contradições do evolver capitalista, não menos certo é que nesse processo tem lugar de importância o problema da cruzada espiritual, religiosa. Não faz muito tempo, o ilustre e simpático historiador francês que é o Prof. Marcel Bataillon, mostrava que houve desde as primeiras vagas de frades que pregavam a conversão no Novo Mundo, um forte sentimento escatalógico da Boa Nova

(17). - J. Capistrano de Abreu, Capitulos de Historia Colonial, 4a. ed., Briquiet ed., Rio de Janelro, 1954, p. 278.

(18). - J. M. de Madureira, S. J. In Revista do Instituto Histórico e Geografico Brasileiro, tomo especial do Congresso Internacional de História da América, t. IV, pp. 238-239. 
(19). Há aí, pois, um interessante problema a estudar. Infelizmente ,não é êste, nem o momento, nem a ocasião para examiná-lo, como seria de desejar.

Visamos apenas, com o que acabamos de dizer, indicar alguns aspectos dessa formação para, a seguir, encararmos o problema da Universidade latino-americana como criadora de cultura, as suas possibilidades e as suas responsabilidades no presente.

A mim, afigura-se que a colonização, como costumamos dizer, ou a conquista, foi uma emprêsa, um curioso empreendimento em que se confundem idéias medievais e outras já marcadamente renascentistas.

Assim, cumpre que investiguemos, ràpidamente embora, o espírito dessa emprêsa para que tentemos compreender, através do seu evolver, o seu próprio ser.

Essa emprêsa, quando a considero à luz da história de meu país, dá-me a impressão de uma grande aventura em que economia e religião, comércio e fé, audácia e desalento andam juntas. E nessa emprêsa vejo dois tipos principais: o aventureiro e o missionário - que no caso brasileiro é o jesuíta.

Ao aventureiro, homem do seu tempo, da agitada Renascença, o nosso Continente abria-se, como esvreve Francisco Romero, como "campo propício a todo o livre esfôrço, para as possibilidades e para a esperança" (20).

A riqueza julgada fácil, atraia o aventureiro e aqui, como diria Gaspar Barleu, "ainda os mais remissos ânimos encontravam estímulos para grandes arrojos" (21).

Contraditório, crédulo e audaz, o aventureiro não se perdia em sutilezas morais ao enfrentar a terra nova e o indígena. Para "além da equinocial não se pecava" (22).

(19). - Marcel Bataillon, "Evangelisme et Millénarisme au Nouveau Monde" in Courants Réligieux et Fumanisme à la fin du XVe. et au début du XVIe. siècle, P. U. F., Paris, 1959, p. 25 e seg. Ver ainda do mesmo autor, "Nouveau Monde et fin du monde, in Revista de História, de Sāo Paulo, n. 18, 1954, pp. 343-351. Cf. ainda John Leddy Phelan, The Millenial Kingdom of the Franciscans in the New World, University of California Press, Berkeley and Los Angeles, 1956.

(20). - Francisco Romero, "Influencias del Descubrimiento de America in Las Ideas Generales"; sep. de Humanidades, t. XXIX, p. 11.

(21). - Gaspar Barleu, História dos feitos recentemente praticados durante oito anos no Brasil, etc., Ed. Ministério da Educação, trad. de Cláudio Brandão, Rio de Janeiro, 1940, p. 19.

(22). - Gaspar Barleu, op. cit., p. 49. 
Opondo-se a êste, o missionário, empenhado, no mais largo sentido da palavra, na conquista das almas, quanto o outro o estava na conquista da riqueza. Na ação do jesuíta, na sua ânsia de conquista espiritual, não se disfarçava o cruzadismo medieval. Assim, ao lado do renome e do lucro, o "sumo zêlo" na dilatação da fé.

$\mathrm{E}$ no entanto, apesar de antagônicos, ambos êstes tipos colaboram numa só emprêsa...

São pois, êstes dois tipos de colonizadores, ou de conquistadores, apenas aparentemente opostos, que se defrontam no alvorecer da nossa história.

Aí se esboçam as contradições da nossa história e de nossa cultura.

Caberá ao aventureiro a conquista da terra, a tarefa de nela abrir caminhos e de plantar cidades.

Ao missionário incumbirá a fundação de colégios, de Universidades, a obra de fixação da cultura humanística européia nesta parte do nosso Continente.

Da dialética que se vai estabelecer em nossa história entre êsses dois tipos de colonizadores, derivará o molde inicial de nossa inteligência e do destino de nossa cultura.

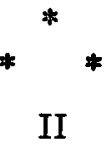

A Universidade - Studium Generale Magistrorum et Scholarum - é uma instituição que se origina na Idade Média (quantas vêzes fico a pensar nisto!) e que apresenta ainda, em nossos dias, mais de uma sobrevivência dessa época...

Embora êste meu julgamento possa ser recusado, é forçoso convir que certos traços do espírito medieval ainda se encontram nos sistemas pedagógicos dos tempos modernos.

"Sua hegemonia - escrevia René Hubert - só se liquidou à medida que se organizava um ensino realista, científico, leigo, destinado à totalidade das nações do Ocidente. Em França, acrescentava o reitor da Universidade de Estrasburgo, grande número de traços espirituais, e até de traços materiais de nossas instituições pedagógicas, ainda se explicam graças a reminiscências do regime medieval" (23).

Mas não é apenas em França que essas sobrevivências espirituais e materiais do regime medieval são encontradas.

(23). - René Hubert, Histoire de la Pédagogie, P. U. F., Paris, 1949, p. 26. 
As universidades medievais deveram seu nascimento a necessidades sociais e políticas da época e nesta, a religião constituia o essencial para o homem, pois a ela subordinava êste tôdas as suas atividades. No evolver do tempo, a instituição universitária iria, porém, adaptando-se, não sem grandes dificuldades e lutas, a outras exigências, nascidas de novas condições de vida social, econômica e política (24). Embora a instituição universitária já tivesse sofrido algumas importantes modificações no século XVI, foi ainda no exemplo da organização e do funcionamento da universidade medieval que se modelaram as universidades renascentistas da Península Ibérica .

A Universidade de Paris que foi o centro de ensino de tôda a Cristandade e padrão universitário por excelência, subordinava todos os estudos à teologia e essa preocupação teológica tão cêdo não desapareceria, chegando mesmo, podemos dizer, até o século XVIII. E' bom que se frise, no entanto, que a Universidade de Estudo, como foi chamada no século XVI, em Portugal e que se transformaria em Universidade, em nada se assemelhava "a um estabelecimento escolar, a um edifício destinado a serviços comuns"; era uma "sociedade de homens unidos por um mesmo espírito e votados às mesmas tarefas. Além disto, esta sociedade não era composta exclusivamente de membros do clero regular e secular. Contava com um grande número de leigos para o ensino de outras disciplinas além das de teologia e teve que sustentar vivas lutas contra ordens religiosas, como a dominicana e a franciscana, que procuravam dominar o ensino teológico" (25), chave mestra - mais o ensino do direito - diríamos, de tôda uma ideologia...

Assim, a função intelectual - e acrescentaríamos: política, da Universidade medieval, visava constituir uma filosofia cristã, perigosa tentativa de racionalização ortodoxa da fé, emprêsa que acarretaria consigo, através das discussões no evolver do tempo, dramáticas vicissitudes para essa racionalização e que desembocaria nas heterodoxias, das quais o erasmismo foi um exemplo que, no dizer de Fernando de los Rios, "representou na Espanha verdadeira guerra civil" (26).

\footnotetext{
(24). - Cf. Antônio José Saraiva, História da Cultura em Portugal, Jornal do Fôro ed., Lisboa, 1950, vol. I, pp. 444 e seg.

(25). - René Hubert, ob. cit., p. 33 .

(26). - Fernando de los Rios, ob. cit., p. 146.
} 
A Universidade portuguêsa durante o século $\mathrm{XV}$ - e talvez possamos dizer o mesmo para a de Espanha - não se alterara sensivelmente.

Verifica-se que "permanece fiel à primitiva estrutura universitária do século XIII" (27), embora "as relações com o poder público sofram uma evolução pela qual ficará grandemente limitada a autonomia universitária" (28).

A teologia e o direito são, pois, desde as origens, os dois polos da Universidade.

"A teologia preparava para as funções diretivas da Igreja e estruturava ideològicamente a sociedade feudal-cristã. $O$ direito romano, em contraste, elaborava juridicamente o tipo de relações social-econômicas provenientes do desenvolvimento da economia comercial. A propriedade real (de coisas) e individual, em que assenta o direito romano, é a negação do senhorio feudal sôbre a comunidade agrária e de laços pessoais, que unem vassalos e suzeranos. As universidades de Bolonha, na Itália, pátria do capitalismo moderno, e de Paris, em França, onde o feudalismo atingiu o seu desenvolvimento máximo, correspondem na realidade a duas ideologias que, por sua vez, exprimem dois tipos de relações humanas, enrajzadas em dois tipos contraditórios de relações de produção. No entanto, o contraste entre os estudos jurídicos e os estudos teológicos não se tornara patente, não se elevara a um plano filosófico, por isso mesmo que os estudos jurídicos universitários tinham um caráter profissional, técnico, e não constituiam, ao contrário dos estudos teológicos, uma síntese ideológica. Só com o surto do Humanismo no século XV assistimos a um conflito entre duas pedagogias conscientemente contraditórias" (29).

Daí resulta a crise da Universidade no século XVI.

"Nestas novas condições - diz ainda Antônio José Saraiva - põe-se o problema da finalidade da educação e da cultura, que só se resolve em função da finalidade do trabalho e da produção, e portanto em função dos objetivos que lhes são propostos pelos grupos que disputam a direção da sociedade" (30).

(27). - Antónlo José Saraiva, ob. cit., p. 445.

(28). - Antônlo José Saraiva, ob. cit., p. 444.

(29). - Antônio José Saraiva, ob. cit., vol. II (1953), pp. 154-155.

(30). - Antônlo José Saralva, ob. cit., vol. II, p. 155. 
Não me detereì a fazer referências ao nascimento das escolas elementares, criadas na Itália e na Liga Hanseática, ou ao esfôrço de humanistas como Juan Luís Vives abrindo escolas públicas. Basta que chame, neste passo, a atenção para o conflito que vai criar nesta época, entre a Universidade tradicional e os novos cursos, como o do Colégio Real de França, criado em 1530 por Francisco I, onde, por exemplo, a matemática passará desde então a ser ensinada com outra amplitude com que fôra tratada até então na Universidade.

Naturalmente, em tudo isto não se cuidava da educação das classes populares, o que constituirá uma conquista tardia pela qual apenas algumas vêzes, bem poucas, bem menos do que lhe cumpria, se interessou ou se tem interessado a Universidade...

Assim, prosseguindo, "a reação das universidades perante as escolas humanisticas exprime a hostilidade inicial da mentalidade e das fôrças tradicionais perante as novidades da Renascença. Mas a Contra-reforma compreendeu lùcidamente a ineficácia dessa reação e tomou, finalmente, o partido de adaptar aos seus fins os novos métodos, os novos programas e as novas escolas, em vez de os combater de frente. Tal foi a posição da Companhia de Jesus, que tomou a peito os problemas pedagógicos suscitados pela crise donde emergiu o mundo moderno" (31).

Ora, dessa crise emergiu também o nosso Continente e sôbre êle influiria, mais do que talvez se pode avaliar, o plano de estudos da Companhia de Jesus - o Ratio Studiorum.

Aliás, cono escrevia o ilustre jesuíta brasileiro, Pe. Leonel Franca, "ao espírito de uma época, ao Zeitgeist dos alemães, não se furta nenhum sistema pedagógico, nem mesmo quando conscientemente se organiza para combatê-lo. O Código de ensino dos jesuítas não se pôde subtrair a esta necessidade e traz, indelével, o cunho do século XVI" (32).

Inácio de Loiola estudara em Paris, assim como os seus primeiros companheiros. Não vinham de "seminários ou de outras instituições religiosas: quase todos diplomaram-se nas melhores universidades da Europa" (33).

Precisamente nessa época, a Universidade de Paris, que era o centro mais brilhante da cultura da Europa "entrava na grande corrente humanista do Renascimento" (34).

(31). - Antônio José Saraiva, ob. cit., vol. II, pp. 161-162.

(32). - Leonel Franca, S. J., o Método -Pedagógico dos Jesuitas - o "Ratio studiorum", Agir ed., Rio de Janeiro, 1952, p. 27.

(33). - Leonel Franca, S. J., ob. cit., p. 28.

(34). - Leonel Franca, S. J., ibidem. 
E se, como é sabido, Santo Inácio freqüentou também as universidades de Alcalá e de Salamanca - "entre tôdas optou decididamente, pela de Paris e mantéve com energia e constância a sua preferência contra resistências, por vêzes, tenazes e profundas" (35).

Seria, pois, o modus parisiensis que dominaria na Universidade do Renascimento, em que logo predominaram os jesuítas.

Se, porém, como escrevia o Pe. Leonel Franca, "no ensino das humanidades a voga da Antigüidade suplantou a tradição escolar da Idade Média, no da filosofia e teologia esta conservou a primazia" (14), e, "sempre que foi possível, os pedagogos jesuítas salvaram a tradição medieval" (36).

O ensino humanístico dos inácianos, como dirá Gonçalves da Câmara ao Padre Mirão, cocnsistiria, assim, em fazer "bons católicos ainda que menos latinos" (37)'

Esse humanismo, todo feito de erudição e de latim, limitava, afinal, o verdadeiro alcance do movimento dos humanistas e transformava-o - ou o afeiçoava - à aquisição de processos retóricos de estilo literário. Dêste modo, o método de ensino dos jesuitas era ainda, como observa Daniel Mornet, em 1762, quase exatamente o que era em 1660, isto é: retórico, e essa retórica foi utilizada, esteve sempre a serviço da luta que o catolicismo daria a tôdas as formas do livre exame originadas da Reforma (38).

Os humanistas, criaram idéias novas, acerbamente criticaram a filosofia escolástica, mas não conseguiram exercer decisiva influência sôbre a velha estrutura da instituição universitária. Esta, até o século XVIII, podemos dizer, não sofreria profundas modificações. Na velha estrutura enxertaram-se as letras, mas manteve-se, como vimos, a escolástica, o mesmo espírito filosófico.

A Universidade passaria a ser, a formadora de belos espíritos, de eruditos, a formadora de bons letrados latinos que, no dizer do já citado do Pe. Gonçalves da Câmara, deveriam ser, de preferência, e com bastante latim: bons católicos...

Essa preocupação, como era natural numa ordem a que incumbia dar combate ao luteranismo, realiza-se no plano de

(35). - Leonel Franca, S. J., ob. cit., p. 29. Cf. James Brodrick, Origines et Expansion des Jésuites, trìd. franc. Spelt ed. Paris; 1950, vol. I, p. 151.

(36). - Antônio José Saraiva, ob. cit., vol. II, $\mathbf{p}_{\text {. }}$ 207:

(37). - Hernâni Cidade, o Selscentismo, in Damiāo Peres, "História de Portugal", Portucalense Bdit., Barcelos, 1934, vol. VI, p. 450.

(38). - Daniel Mornet, La Pensée Française au Xvirre. slècle, Collin ed., Paris, 1932, pp. 5-6. 
estudos dos jesuítas: Na Regra 16.a do Provincial, prescreve o Ratio Studiorum: "Os professôres de filosofia (exceto caso de gravíssima necessidade) não só deverão ter concluído o curso de teologia senão ainda consagrado dois anos à sua revisão, a fim de que a doutrina lhés seja mais segura e mais útil à teologia. Os que forem inclinados a novidades ou demasiado livres nas suas opiniões deverão, sem hesitações, ser afastados do magistério" (39).

Do mesmo modo, na Regra 2a. do professor de filosofia, está dito: "Em questões de alguma importância não se afaste de Aristóteles, a menos que se trate de doutrina oposta à unânimemente recebida pelas escolas, ou, mais ainda, em contradição cam a verdadeira fé. Semelhantes argumentos de Aristóteles ou de outro filósofo contra a fé, procure, de acôrdo com as prescrições do Concílio de Latrão, refutar com todo vigor" (40).

A Companhia de Jesus, ordem religiosa que se vai empenhar na Contra-Reforma, que vai até caracterizar essa ContraReforma, foi uma notável criação do espírito aventureiro da época.

"Destinada às missões no exterior, logo utilizada pelo $\mathrm{Pa}-$ pado para a luta contra os progressos da Reforma, concebida de maneira a poder viver no mundo embora guardando o caráter (de clero) regular; muito diferente, por conseguinte, das antigas congregações enclausuradas da Idade Média, habilitada, aliás a preencher tôdas as funções do clero secular, apta a adaptar-se às idéias e aos costumes novos, sabendo, graças a uma casuística subtil, manter os dogmas e os preceitos fundamentais, pondo-os aliás ao alcance da fraqueza humana em geral e também, os gostos da burguesia enriquecida, a ordem compreendeu logo que a educação da mocidade devia ser o seu principal meio de luta" (41).

E' estranho mas compreensível, quando consideramos os dados da história econômica que, no momento mesmo em que os dois países da Península Ibérica se cobriam com as glórias dos Descobrimentos, caminhassem para a sua decadência.

Portugal lançara-se, febrilmente, à atividade da emprêsa marítima.

(39). - Leonel Franca, S. J., ob. cit., pp. 112-123.

(40). - Leonel Franca, S. J., ob. cit., p. 159.

(41). - René Hubert, ob. cit., p. 49. 
"O papel libertador que teve, na Itália, a atividade industrial, teve-o entre nós - escreve Antônio Sérgio - a Navegação. Ela nos forçou ao exame direto dos fenômenos da natureza. As necessidades da pilotagem nos conduzem ao estudo das matemáticas, que aqui culminam com Pedro Nunes; e a visão assídua de espetáculos novos - de novas terras, de novos mares, de climas novos e de estrêlas novas - mostrava aos portuguêses, a cada passo os erros enormes das Autoridades, a cujas afirmações se prestara fé como a revelações do próprio Deus" (42).

A visão de uma outra realidade, a experiência de um mundo novo permitiu aos navegadores notar quanto andavam enganadas as autoridades tradicionais, principalmente a grande autoridade até então: Aristóteles, em relação à física, à cosmologia. E assim, perderam êsses navegadores a atitude de superstição perante os textos.

"Eram as flâmulas do Espírito Crítico que nos vinham sopradas dos mares longínqüos e içadas nos topes de nossas naus"; "sabe-se mais em um dia agora pelos portuguêses, do que se sabia em cem anos pelos romanos", dirá Garcia da Orta, que, por volta de 1515, fôra estudante em Salamanca (43).

Mas êste mesmo esclarecido espírito, no Colóquio da Maçã e da Noz, do seu grande livro Colóquios dos Simples e Drogas da india, impresso em Goa em 1563, referindo-se à atmosfera intelectual então reinante na Península, respondia ao seu imaginário interlocutor Ruano, que lhe perguntava acêrca da opinião dos antigos sôbre a noz moscada: "Fêz isso porque havia mêdo de dizer coisa contra os gregos e não vos maravilheis disto, porque eu, estando em Espanha, não ousaria dizer coisa alguma contra Galeno e contra os gregos" (44), afirmação que revela, já na segunda metade do século XVI, que o humanismo português estava submisso a autoridade dos antigos e que já então se estiolava o notável surto de crítica que fôra contemporâneo dos Descobrimentos.

E' mister não esquecer: em 1580, a Companhia de Jesus já possuia 155 colégios que, de certa forma, concorriam com as universidades. E, "quando tôda a evolução anterior havia levado as Universidade a tornarem-se progressivamente leigas em tudo quanto não fôsse ensino de teologia e de direito canô-

(42). - António Sérgio, Ensalos, Seara Nova ed., Lisboa, 1928, tomo II, p. 29.

(43). - Cf. Conde De Ficalho, Garcia da orta e o seu Tempo, Imprensa Nactonal, Lisboa, 1886-1891 - 2 vols.

(44). - Garcia da Orta, Colóquios des simples e Drogas da India (ed. dirigida e anotada pelo Condé de Ficalho), Lísboa, Imprensa Nacional, 1892, vol. II, pp. 83-84. 
nico, a educação, entre as mãos dos jesuítas, tendeu a tornar-se novamente, como há três ou quatro séculos antes, monopólio de uma ordem religiosa" (45), que não se apartava da autoridade de Aristóteles... Assim "o espírito português do Quinhentismo - foi promessa que se não cumpriu" (46).

E' muito discutida a educação jesuítica. Ela visaria unir a piedade $e$ as letras, afirmam uns - e assim teria sido no século XVI; tenderia, em virtude de razões políticas, a alienar o honnête home das paixões e idéias do século, dizem outros; nela existiria, afirmariam outros ainda, a tendência para considerar o homem in abstrato, para educá-lo em vista da Humanidade - e assim sua pedagogia assemelhar-se-ia a de Augusto Comte - dando-lhe, dêsse modo, importante papel na formação do espírito revolucionário. E' bom lembrar que nenhum sistema pedagógico consegue furtar-se ao espírito da época, pois é sempre reflexo do próprio condicionalismo histórico.

Assim, o próprio monopólio da educação pelos jesuítas, traduz problemas mais profundos a que, de passagem fiz referência, mas que não cabe aqui aprofundar.

O Seiscentismo em Portugal será, pois, sob o ponto de vista intelectual, o "espetáculo do estiolamento da mentalidade portuguêsa". "Depois dos dias do Quinhentismo, o que se chama espírito moderno - diz ainda o ensaísta Antônio Sérgio - não mais vigorou na nossa terra" (47).

Não parece ter sido muito diferente dêste, o quadro espanhol. O historiador Rafael Altamira assim intitula a um dos capítulos de sua História de la Civilización Española: "a hegemonia española y la decadencia", correspondendo êsse trecho, de 1517 a 1700 .

Se até então houvera um verdadeiro impulso dado à cultura e se muitas haviam sido, e eloqüentes, as manifestações do saber, entre elas a criação da Universidade de Alcalá de Henares, para não falar dos centros de estudos científicos como os das escolas maiorquinas e catalãs e da Casa de Contratação (48), no entanto, o "império no qual nunca se ocultava o sol", logo entraria em decadência. O intransigente catolicismo dos reis na luta contra a difusão do protestantismo, o desêjo de "conservar a pureza ortodoxa na Península, fêz diminuir e até

(45). - René Hubert, ibidem.

(46) . - Antônio Sérgio, ob. cit., p. 19.

(47). - Antônio Sérgio, ob. cit., p. 20.

(48). - Rafael de Altamira, Fistoria de la Cicilizaclón Española, Espasa-Calpe ed., Madri, 1932, p. 162 e segts. 
cortar pela raiz, a comunicação intelectual com outros países; considerar como suspeitos os estrangeiros e cortar a liberdade dos professôres e escritores nacionais em relação a tudo quanto dizia respeito ao dogma ou em que houvesse suspeita de que pudesse relacionar-se com êle" (49).

De tal modo, as universidades espanholas, em meados do século XVIII, conforme escreve ainda Altamira, na "sua maioria arrastavam vida lângüida e, penosa. [...] Porém, o mais grave na esfera universitária era a decadência dos próprios estudos, cujo sistema livresco, memorista, cujo espírito estreito, cheio de preocupações de rotina, não se prestava, de nenhum modo, a impulsionar a investigação científica. Cristalizado o saber em fórmulas tradicionais, cuidavam tão pouco os professôres dos progressos de seu século que, em 1781, a biblioteca da Universidade de Alcalá contava, entre 17.000 volumes, apenas 50 expressivos das doutrinas correntes em outros países" (50).

Como diz Fernando de los Rios, "los canones del Concílio de Trento devinieron la ley del país" (51).

"Era a Espanha, - diz por sua vez o historiador da cultura portuguêsa, Hernâni Cidade - era a Espanha o país com que mantínhamos mais assíduo convívio intelectual. E como, se bem divergente sob tantos aspectos, a êste respeito forma ela com Portugal um bloco espiritual homogêneo, tôda a Península constituindo o que se chama a Ilha da Purificação"... (52).

Era esta a atmosfera cultural existente na Península quando se iniciou a nossa colonização. Será ainda esta a que se prolongará até o século XVIII. A Colônia irá ressentir-se com tal legado.

A Península Ibérica era, ao se iniciar a colonização desta parte do nosso Continente, como vimos, uma verdadeira ilha da Purificação...

(49). - Rafael de Altamira, ob. cit., pp. 172-173.

(50). - Rafael Altamira, Historia de Espafia, vol. IV, p. 323, apud J. Ingenleros, La Evolución de las Ideas Argentinas, La Revolución, Buenos Aires, 1918, vol. I, pp. 32-33.

(51). - Fernando de los Ríos, ob. cit., p. 151.

(52). - Hernáni Cidade, Liçóes de Cultura e de Literatura Portuguêsa; Coimbra Ed., Colmbra, 1939, II vol., p. 22. 
A subordinação, durante quase dois séculos, a uma pedagogia vigilante, preocupada sobretudo em desviar a inteligência peninsular de quanto a pudesse conduzir à heterodoxia e de a fazer - como diria o próprio Pe. Vieira: "requinte de finezas", jôgo de conceitos, quando perigosa era a reflexão sôbre idéias - foi uma das razões de um certo formalismo do qual, talvez ainda padeçamos.

E' nessa pedagogia, quase diríamos, nessa "filosofia da educação" que a nossa cultura intelectual tem raízes.

O complexo conjunto de novas condições e circunstâncias que com o passar do tempo se imporia ao europeu ou aos seus descendentes na América, como que impunha que as idéias de importação, umas se perdessem e outras fôssem aproveitadas, transformadas, ou afeiçoadas. Assim, os velhos moldes e instrumentos da cultura intelectual - e no caso, a Universidade aqui dariam resultados raquíticos, canhestros, por não chegarem a traduzir o que de novidade existia na nossa experiência.

"Colocado em uma nova situação - para a formação da qual concorriam um meio físico, e uma organização social e econômica peculiar - tinha o homem que criar um estado de espírito diferente, atitudes, desejos, esperanças, idéias, uma sensibilidade e psicologia, em suma uma nova concepção da vida e das relações humanas, uma visão própria da realidade" (53).

A Universidade, instituição marcada pelo cunho medieval e pelas vicissitudes por que passou nos séculos XIV, XV e XVI, não correspondia - e talvez ainda não corresponda - à trepidação, ao dinamismo de nossa vida que é, como justamente observou Ortega y Gasset, em um dos seus trabalhos, etapa, periołdo, que está sempre a tender para uma nova etapa, para um outro momento...

"Ouço dizer", escrevia o brilhante ensaista espanhol, referindo-se a críticas sôbre a universidade argentina - "que ela não vai bem". "Nada mais faltava que já estivesse bem! Seria monstruoso - acrescentava - seria desesperador que a Universidade já estivesse completamente bem na Argentina" (54).

De minha parte, por vêzes fico a imaginar se a Universidade, em nossos países, não será um corpo estranho, talvez uma excrescência?... Desde cêdo ela lutou para expressar valores necessários e universais mas nunca chegou a traduzir êsses valores de uma maneira adeqüada, que fôsse sua, talvez

(53). - Afranio Coutinho, Introdução Geral, : In “A Literatura no Brasil", Sul Americana Ed., Rlo de Janeiro, 1956, vol. 1, t. I, pp. 51-52.

(54). - Ortega y Gasset, Meditación del Pueblo Joven, Emecé ed., Buenos Atres, 1958, pp. 69-73. 
pelo fato de não refletir exata e adeqüadamente as situações criadas pela nossa experiềncia. Foi Alberdi quem disse: "temos já uma vóntade própria, falta-nos uma inteligência própria" (55).

No mesmo sentido opinaram quase todos os intelectuais do nosso continente no século XIX, acentuando todos, porém, a existência de uma forma própria de ver, o que Alberdi, perene proscrito, não vislumbrava (56)

No entanto, como escreveu o saudoso Alfonso Reyes, "é possível agora falar com maior propriedade de uma inteligência americana que de uma cultura americana; inteligência cujas características consistem em ser: menos especializada que a européia; mais extensiva que compreensiva e, portanto, "algo asi como una delgada corteza en perigo de quebrar-se" (57), até nas elites", e de desfazer-se, em virtude, a meu ver, de razões diferentes das que o ilustre pensador mexicano apontava...

Que a nossa Universidade não vai bem, é certo, mas certo é também, que não é caso para desesperar.

O missionário acompanhou o aventureiro na emprêsa dos Descobrimentos e da colonização. Está presente desde a chegada das primeiras caravelas. Era franciscano o primeiro sacerdote que nesta parte do nosso continente oficiou o seu culto. Seu nome - Frei Henrique Soares, da cidade de Coimbra, aparece no lindo atestado de nascimento do Brasil que é a carta de Pero Vaz de Caminha. Com frei Henrique estavam mais sete missionários (58).

Franciscanos, dominicanos, carmelitas, beneditinos e jesuítas tiveram, desde cêdo influência decisiva nas colônias ibéricas da América. Em 1510 chegavam os primeiros dominicanos à Isla Española, e já no domingo anterior à festa do Natal, conta-nos Sílvio Zavala, frei Antônio de Montesinos pregava.

"Sou a voz de Cristo no deserto desta ilha... Esta voz é de que estais em pecado mortal e nele viveis e morreis pela cruel-

\footnotetext{
(55). - Alberdi, Estudios Jurídicos, 1, p. 20, apud Alberto Sanchez, Existe America Latina?, Fondo de Cultura, Méxfico, 1945, p. 229.

(56). - Alberto Sanchez, ibidem.

(57). - Alfonso Reyes, Notas sobre la Inteligencla Americana, in "La Vanguardia", de Buenos Aires, de 23 de maio de 1937, apud Alberto Sanchez, ob. cit., pp. 229-230.

(58). - Cf. Freí Basilio Röwer, A Ordem Franciscana no Brasil, 2a. ed., Vozes de Petrópolts Ed., Petrópolis, 1947.
} 
dade e tirania que usais com estas inocentes gentes. Não são êles homens? Não possuem almas racionais?" (59).

Os primeiros atritos e as primeiras incompreensões entre os dois tipos de colonizadores, já aí tinham início. Dois modos de entender a aventura americana ali desabrochavam: a do frade, a reclamar "severa sujeição da conduta terrena à lei cristã", usando "da liberdade própria de seu estado para fustigar do púlpito os abusos sociais".

E' verdade - diz ainda Sílvio Zavala - que "nem todo o clero se manteve fiel a êstes elevados princípios, nem sua vigência foi constante através dos três séculos coloniais. A Igreja monopolizou bens agrários e urbanos, acumulou capitais que dava em empréstimo e exigiu também serviços e contribuições do índio" (60), enfim, sua ação não se limitou apenas à conquista das almas. Esta se faria pela pregação e pelo ensino.

"Tudo, na vida intelectual, gira em tôrno da igreja e dos colégios, de que parte o único apêlo às coisas do espírito, os únicos focos luminosos nessa vasta zona de sombra".

O ensino - escreve Fernando de Azevedo ao estudar a Escola e a Literatura "impregnado ainda do espírito medieval que se dava nesses colégios, para a formação de clérigos, letrados e eruditos, posto a serviço da religião e de uma classe, embora se dirigisse também a jovens mais aptos, recrutados nas camadas populares, atendia à̀s exigências e aspirações não só da Igreja como das famílias das casas-grandes e da burguesia das cidades que tomavam ràpidamente o gôsto das sociedades aristocráticas" (61), gôsto que se manifestava sobretudo na forma literária peculiar ao humanismo renascentista. Assim é que soldados como Fernão Cortez já se rodeavam de uma pequena côrte literária da qual foram frutos algumas obras de Gôngora (62).

Dêste modo o que nos três séculos da Colônia se ensinou, foi aquêle mesmo humanismo a que já nos referimos e que tendia a fabricar eruditos retóricos, requintadores de finezas, regulares latinistas mas, sobretudo, submissos e bons católicos. Foi êsse humanismo, curiosa resultante de uma incipiente civilização patriarcal, latifundiária e escravocrata, que criou a cultura ornamental a que já tive ocasião de me referir e da qual não faz muito começamos a nos libertar.

\footnotetext{
(59). - Sílvio Zavala, La Filosofia de la Conquista, Fondo de Cultura, México, 1947 , p. 78

(60) : - Ślvio Zavala, Aproximaciones a la Historia de Mexico, Porrua y Obregon ed., México, 1953, pp. 16-17.

(61). - Fernando de Azevedo, A Escola e a Literatura, in "A literatura no Brasil”, Sul Americana Ed., Rio de Janeiro, 1956, vol. I, t. I, p. 131.

(62). - Sílvio Żavala, ob. cit., p. 20.
} 


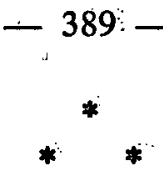

Pouco sei acêrca do ensino e da Universidade nos países sul-americanos de origem espanhola. As bibliotecas nacionais são muito pobres em livros e em obras, em fontes relativas a estas questões, quando o contrário é que devia ocorrer.

No entanto, pelo que afirmam Fernando de los Rios e Hernâni Cidade, que tive ocasião de citar, suspeito que a situação do ensino e da Universidade nos países de origem ibérica, tendo em conta a atmosfera reinante na Península nos séculos XVI, XVII e XVIII deveria ter sido algo semelhante ao que se passava na mesma época em meu país. Portugal e Espanha formavam então - e formam ainda hoje - um bloco espiritual mais ou menos homogêneo. Creio que não é necessário que justifique o que digo com maiores, mais claros e hodiernos exemplos...

A cultura espanhola, porém, apesar da progressiva decadência econômica e política da nação, conservou-se mais viva e influente no século XVII que a portuguêsa. O século XVII português, se teve importância sob o ponto de vista intelectual, esta consistiu na restauração ida Escolástica, verdadeiro imperativo dos jesuítas na época, e que seria, aliás, o mais importante fruto do monopólio do ensino superior; obtido por êles em 1545 (63). Assim, o famoso Cursus Conimbricencis, iniciado em 1577 com o comentário de Pedro da Fonseca à Metafísica de Aristóteles, que era utilizado em Coimbra, também o era nos colégios do Brasil, embora não fôsse o único. Outras obras também serviam aos "filósofos" brasileiros do século XVII, como por exemplo, a Summa Universae Philosophiae, de Baltazar Teles, publicada em 1542 (64).

Ensinar e propagar a doutrina teológica, uma filosofia militante, tal foi a finalidade da ação hábil, multiforme e inteligente da Companhia de Jesus. Foi essa ação multiforme e realista dos jesuítas que explica (ao menos em parte, a meu ver) uma série de questões referentes à nossa história intelectual.

(63). - Cf. Joaquim de Carvalho, Leibniz e a Cuitura Portuguêsa, separata das "Memórias da Academia de Ciências de Lisboa", T. V., Lisboa, 1949, pp. 6-10.

(64). - Pe. Serafim Lelte, S. J., História da Companhia de Jesus, Instituto Nà: cional do Livro, Rio de Janeiro, 1949, t. VII, pp. 219-221. Cf. Alcides Bezerra. Achêgas à. Fistórit da Filosofia: a filosofia na fase colonial, "Arquivo Nacional", "Rio de Janeiro, 1916, passim Cruz Costa, Contribuicáo à Historla das Idéias no Brastl, José olímpio ed., Rlo de Janetro, T956, 1a. parte, cap. I. 


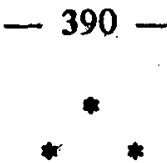

"A Espanha - escrevia Pedro Henriquez Ureña - deu às suas colônias uma organização de cultura tão completa quanto a que ela mesma possuia, o que não se deu com Portugal. Pelo fato de estar o Brasil mais próximo de Lisboa que qualquer outro domínio espanhol, ali não se estabeleceram instituições de cultura superior" (65).

Não me parece que as razões de Pedro Henriquez de Ureña sejam procedentes neste passo.

Efetivamente, enquanto os colégios de frades franciscanos e dominicanos da América espanhola logo se transformavam em Universidades, desde as mais antigas, a de São Marcos, de Lima; a de São Domingos e a do México - que datam do século XVI, até as mais recentes: a de São Gregório Magno, dos jesuítas, em 1620, em Quito; a de São Francisco Xavier, em 1624, em Charcas; a de Santo Inácio de Loiola, de Córdoba; a de Santa Rosa, em 1725, em Caracas; a de São Jerônimo, em 1728, em Havana - ao todo vinte e seis universidades na América Hispânica (66) - no Brasil não houve universidade até o século $\mathrm{XX}$. A primeira que se fundou em meu país, tem apenas vinte e cinco anos - a Universidade de São Paulo, criada a 24 de janeiro de 1934 .

Em meados do século XVII houve porém uma tentativa para a criação da Universidade no Brasil. Mas já desde 1572, havia muitos cursos de filosofia, pois o primeiro dêles, como escreve o Pe. Serafim Leite, "leu-se" naquele ano (67).

Os Colégios das Artes - verdadeiras faculdades de filosofia, onde ensinavam os jesuítas - já realizavam doutoramentos desde 1575 e existiam em várias regiões do Brasil, no Rio de Janeiro, em São Paulo, em Olinda, no Recife, no Maranhão e no Pará (68).

Em meados do século XVII, tratou-se da dar àqueles colégios, um estatuto legal, "de fazer que a Faculdade fôsse de direito real ou civil, e também a de Teologia, no mesmo pé de igualdade" (69) com as Universidades da Metrópole. O Brasil "julgava-se com direito à regalia, porque já então dispunha de

(65). - Pedro Henriquez Urefia, História de la Cultura en la America Hispanica, Fondo de Cultura, México, 1949, p. 46.

(66). - Cr. Pedro Henriquez Ureña, Historia de la Cultura en la America Hispanica, Fondo de Cultura, México, 1947, pp. 41-43.

(67). - Serafim Lette, ob. clt., p. 191.

(68). - Serafim Lelte, ob. clt., vol. I, p. 97; vol. VI, p. 4; vol. V, p. 132, vol. V, p. 484; vol. I, p. 285 .

(69). - Serafim Leite, ob. cit., vol. VII, p. 194. 
juventude abundante e a guerra contra a Holanda desenvolvera a consciência de sua própria importância dentro da Comunidade Portuguêsa" (70).

O desêjo de possuir uma Universidade coincidia, assim, com as primeiras manifestações nativistas.

Basta dizer que em resposta a dois ofícios da Câmara da Bahia, de 20 de dezembro de 1662 e de agôsto de 1663 , no sentido de se conceder uma Universidade ao Brasil, a Universidade Portuguêsa declarava que "não era conveniente" que se respondesse a tal pedido! (71). Para aquilatar do valor e do alto grau de ensino do Colégio da Bahia, basta lembrar que ali fêz os seus estudos - e a êle deveu tôda sua formação uma das mais altas figuras da própria literatura portuguêsa, o Pe. Antônio Vieira...

No século XVII cresce a importância econômica do Brasil. A experiência da dominação e da guerra holandesas, os engenhos de açúcar, haviam pôsto em foco o país. Os próprios letrados compreendem os interêsses da terra, pois a sua história começa a ser escrita. E' dêsse tempo a História do Brasil, de Frei Vicente do Salvador.

A Companhia de Jesus também tinha interêsse na criação da Universidade, ela que espalhara pelo país, em tão pouco tempo, tantos Colégios. Assim, em resposta a uma nova representação da Câmara da Bahia, dizia o Provincial Alexandre de Gusmão: "eu particularmente desêjo muito o aumento dos Estudos como coisa de tanta utilidade para o bem comum" e "prometo fazer de minha parte tôda a diligência" (72).

Empenhada em ensinar e propagar a fé, voltada sua atenção sobretudo para a educação e conquista das almas dos jovens, a Companhia sempre revelou, porém, maior inclinação e interêsse pelo ensino secundário, ao qual corresponde a fase decisiva da formação do homem. Não se descuidava, no entanto, do ensino superior. Mas, como boa milícia que devia ter em conta todos os dados para a batalha que ia empreender, não desconhecia o terreno em que se encontrava.

Cumpria que os jesuítas formassem, com os naturais da terra, aquêles que viessem a substituí-los mais tarde na catequese. De início, julgou-se que êstes naturais, indígenas ou os que nascessem na Colônia, seriam tão aptos quanto os das In-

(70). - Serafim Lette, Ibidem:

(71). - Memórias da Universidade de Coimbra, ordenada por Francisco Carnetro de Figueir6a, pp. 227-228, apud Serafim Lelte, ob. cit., p. 196.

(72). - Serafim Leite, ob. cit., p. 200. 
dias Orientais e do Japão, "de onde chegavam a Portugal informações maravilhosas. A desilusão não se fêzz esperar no que toca à elevação dos índios ao Sacerdócio, não por incapacidade radical dos mesmos índios, pois eram homens - diz o Pe. Serafim Leite, que vimos citando - e os homens são todos iguais, mas por falta de meio ambiente, ainda inculto, e era o que o Pe. Antônio Vieira advertia, propondo que o Catecismo na Língua Brasílica, do Pe. Antônio de Araujo para os índios, se reduzisse a menos questões, simples e essenciais" (73), cartilha de doutrina cristã que deveria ser feita, como dizia. Vieira, "para gente de diferente saber e entendimento" (74).

Com a perspicácia e o realismo de que é dotada, a Companhia de Jesus compreendeu que o "desnivel de cultura entre os habitantes dac cidades do Oriente os filhos das florestas do Brasil tornava impossível a imediata elevação dêstes a estudos superiores e a chefes e guias de cristãos; não era o mesmo já nos filhos dos brancos, ainda quando nasciam de índias e negras. Para os filhos dos brancos ou de tronco branco nos seus cruzamentos e gerações sucessivas, nas vilas e cidades que surgiam do nada no Brasil, se criaram, pois, e permaneceram patentes e públicos os colégios durante dois séculos" (75), freqüentando-os os filhos dos senhores de engenho, de funcionários reinóis, gente que, se a comparação fôsse possível, corresponderia à nobreza e burguesia da Europa - e também os que iriam constituindo, muito lenta e sem grande significação, os núcleos da pequena burguesia urbana do Brasil do século XVIII (76) .

A cultura intelectual era, assim, um sinal de classe, prerrogativa que não se aplicava, puro ornamento ou recreio destinado "marcar mais nitidamente a diferença entre a pequena casta privilegiada e a massa ignorante" (77).

Em face da inexistência de uma cultura indígena, como a que os conquistadores encontraram no México e no Perú, no Brasil tudo estava por fazer. Tem razão, pois, Sérgio Buarque de Holanda quando diz que "nem o contacto e a mistura com as raças aborígenes, fizeram-nos tão diferentes dos nossos avós de além-mar como gostaríamos de sê-lo. No caso brasileiro, a verdade, por menos sedutora que possa parecer a alguns dos nossos patriotas, é que ainda nos associa à Península Ibé-

(73). - Serafim Leite, ob. cit., p. 142.

(74). - Carta Inédita de Vieira, de 1656, publ, na "Brotéria", vol. XLV (nov 1947), 465, apud Serafim Leite, ibidem.

(75). - Serafim Leite, ibidem.

(76). - Cf. Serafim Leite, ob. cit., p. 143.

(77). - Fernando de Azevedo, A Cultura Brasileira, Melhoramentos Ed., São Paulo, 1958, 3a. ed., t. II, p. 80 . 
rica, e a Portugal especialmente, uma tradição longa e viva, bastante viva para nutrir até hoje uma alma comum, a despeito de tudo quanto nos separa" (78).

E essa tradição, no que toca à cultura intelectual, é tôda ela marcada de um sentido utilitarista, imediatista, alheia "aos enlevos da imaginação e às criações puramente artificiais do espírito" (79), pouco atenta à fantasia sem proveito, como dizia el-rei D. Duarte: Um "terrestre amor das realidades humanas" (80), caracterizaria a cultura portuguêsa. Tal é, assim julgo, o fundo da concepção do mundo e do homem que os brasileiros herdaram da tradição portuguêsa e a que vai misturar, a resignação e a rebeldia, do negro e do índio... Daí o nosso idealismo não se afastar muito longe da terra, como dizia o irônico João Ribeiro... (81).

Falou-se de um milagre grego. Há, porém, outro "milagre": o do século XVII - o século de ouro do novo espírito científico, ou do espírito científico.

"O mérito inegualável do século XVII não consistiu em haver visto mais ou menos bem mais coisas de que haviam visto os predecessores, mas o de haver considerado o mundo com novos olhos" (82).

Esta revolução não ressoaria em Portugal. E há, ainda hoje, quem justifique êsse isolamento de Portugal em relação à revolução científica do século XVII!... (83).

À renovação do saber empreendida por tal revolução, opunha a Península, a sutileza da silogística!

"Em tôrno do magro texto aristotélico - escreve Hernâni Cidade - a bordadura densa dos comentários" (84).

Por tôda a parte vai intensa a revolução filosófica... menos na Península.

(78). - Sérgio Buarque de Holanda, Raiizes do Brasil, José Olímpio ed., Rio de Janeiro, 1a. ed., 1936, p. 15 .

(79). - Costa Marques, D. Duarte e o Leal Conselheiro, Liv. Clássica ed., Lisboa, 1942, p. 7 .

(80). - João de Barros, Pequena História da Poesia Portuguêsa, Cosmos ed., Lisboa, 1941, pp. 41-42 e 96 .

(81). - João Ribeiro, A Filosofia no Brasị,, in "Revista do Brasil", n.o 22, ano II, vol. VI, p. 255 .

(82). - R. Lenoble, Le XVIIe. siècle, in "La Science Moderne (Híst. Générale des Sciences", sob a direção de R. Taton), P. U. F., París, 1958, vol. II, p. 186.

(83). - Cf. Alvaro Ribeiro, O Problema da Filosofia Portuguêsa, Inquérito ed., Lisboa, 1943, p. 15.

(84). - Hernâni Cidade, Liçōes sôbre a cultura e a Literatura Portuguêsa, vol. I, p. 190 . 
Demoraria algum tempo para que o espírito científico penetrasse na Península e mais ainda, naturalmente, em suas colônias.

"Como na Idade Média, guardadas as diferenças, tôda ordem de conhecimentos constinuava nesses países de colonização lusitana ou espanhola, escreve Fernando de Azevedo, tributária da religião, e a subordinação à Igreja e ao tipo de cultura de que era depositária, marcava com um dos seus caracteres principais, as escolas que se fundaram, modeladas segundo os velhos padrões $[\ldots]$. Posto que colorida de matizes diversos na sua orientação, conforme a preponderância dessa ou daquela ordem religiosa a que se atribuiam as tarefas do ensino (os jesuítas em primeiro lugar entre nós e os franciscanos, beneditinos, carmelitas com maior destaque, nas outras colônias), a cultura que se transferiu de Portugal e de Espanha, alimentada numa fonte comum, apresentava os mesmos caracteres e as mesmas tendências fundamentais" (85).

Por isso mesmo, acrescenta ainda Fernando de Azevedo, "a criação de universidades nos séculos XVI e XVII nas colônias espanholas da América não contribuiu senão para aí desenvolver e fortificar o espírito medieval que animava essa cultura no país de origem" (86).

Essas escolas - universidades e colégios - fixaram na América, os padrões de uma cultura intelectual superior, de classe, mais ornamental que investigadora, não contribuindo senão em pequena parte para o nascimento de um verdadeiro espírito criador de cultura. Aliás, em Portugal, e em Espanha, como refere Altamira, as Universidades "arrastavam vida lângüida e penosa" (87), revelando-se incapazes de tal criação.

\section{IV}

Foram as Universidades e os Colégios, fundados pelas ordens religiosas durante o período colonial, que fixaram em nosso continente os padrões de uma cultura superior universitária, reflexo que eram das condições do ensino, no momento em que terminava a Idade Média e se iniciava o Renascimento. Essa cultura foi uma cultura de classe - ornamental ou de recrea-

(85). - Fernando de Azevedo, Introdução, in "As clênclas no Brasil", Melhoramentos ed., Săo Paulo, 1955, vol. I, p. 18.

(86). - Fernando de Azevedo, lbidem.

(87). - Rafael Altamira, Historta de Espafia, vol. IV, 323, apud José Ingénleros, ob. cit., p. 32. 
ção - que serviu para diferenciar uns poucos, da grande massa de ignorantes.

No Brasil, os jesuítas, monopolizadores do ensino público no Reino, ao lado dos Colégios - incipientes faculdades de filosofia e de teologia - fundaram também as primeiras escolas de ler e de escrever.

Mas para a época, para os seus ideais políticos - mesmơ na Europa - a educação popular não interessava, salvo talvez aos protestantes. Rudimentar, a educação do povo era completada pelos jesuítas, no púlpito e pelo teatro. A educação popular, é aliás uma conquista tardia e revolucionária; não podia e nem devia interessar nos tempos coloniais e, tão pouco interessou ao Reino Unido.

Em Portugal e nas colônias o ensino primário data da Carta Régia de setembro de 1772, pela qual o Marquês de Pombal criou o chamado subsídio-literário, destinado à manutenção de escolas de primeiras letras e do magistério novo - o dos mestres-régios - visava acabar com o desprêzo "que andava ligado àquela profissão até então considerada mecânica" (88) .

Tal criação era "um sonho ou um simples disfarce, para contrabalançar o efeito do fechamento dos colégios dos jesuítas conseqüente à expulsão da Companhia, alguns anos antes" (89) .

Com a vinda da família real portuguêsa para o Brasil a si-. tuação educacional não se modificara.

"A cultura do povo ainda não deveria ser sentida como necessidade de organização nacional. A educação acadêmica, sim. E. D. João VI ou seus estadistas agiram com perfeita compreensão do problema, criando, desde logo, escolas superiores. A ralé não podia interessar. Vivia, e devia viver, no eito" (90) .

Não nos cabe aqui fazer (e nem poderíamos fazer) - o que seria, talvez, de grande importância para a verdadeira compreensão do significado da cultura na América Latina - um estudo da educação ou da falta de educação popular. Mais adiante, quando nos referirmos às responsabilidades da Universidade como criadora de cultura, esperamos voltar a êste problema que é, por certo, o nosso problema essencial.

\footnotetext{
(88). - D. Antônio da Costa, Eistória da Instruḉo pablica em Portuçal. Figuelrinhas ed., Pórto, 1900, p. 106.

(89). - Lourenço Filho, prefíclo in M. A. Telxetra de Freltas, o Ensino Primárto no Brasil, Melhoramentos ed., São Paulo, s-d., p. 4 ,

(90). - Lourenço Filho, ibidem.
} 
Em meados do século XVII haviam os baianos, como vimos; pleiteado estabelecer, no Salvador, uma Universidade.

Ao findar o século XVIIT essa idéia revive entre os Inconfidentes.

"Na Vila Rica - diziam êstes - se haviam de abrir estudos como em Coimbra, em que também se aprendessem leis". (91).

E' bem que se note: onde se aprendessem leis - expressão que traduz exigência de organização administrativa e jurídica que ia a par com os anseios de autonomia. Assim, logo que o Brasil se tornou independente, o Império criou as duas mais antigas faculdades de direito, a de São Paulo e a de Olinda, ainda à sombra de dois conventos, o de São Francisco e o de São Bento.

A partir do século XVIII, a influência francesa começava a se exercer no Brasil. Separando-nos de Portugal, voltamonos para a França cuja "missão nessa época foi a de acordar, instruir e guiar as nações" (92).

As idéias dos Enciclopedistas difundiam-se na América latina através dos seus livros que não eram lidos, diz Ureña, muito em segrêdo. Montesquieu, Voltaire e Rousseau contavam-se entre os autores de maior influência (93). Na América portuguêsa o mesmo se dava e o testemunho disto são as bibliotecas de alguns dos conjurados mineiros. Na livraria do Cônego Luís Vieira da Silva encontravam-se, além de volumes da Encyclopédie, de Diderot e de D'Alembert, livros de Voltaire, de Montesquieu, aje Marmontel ao lado das obras completas de Santo Agostinho e de Santo Tomás (94).

A vinda da família real portuguêsa para o Brasil, transformaria a situação cultural do país.

D. João VI criou, a partir de 1810 uma biblioteca pública, a futura Biblioteca Nacional; uma Imprensa Régia - quando em julho de 1747, uma Carta Régia que deslustra a administração portuguêsa havia ordenado a destruição da oficina tipográfica do jesuíta Pe. Francisco de Faria, mandando "seqüestrar e remeter para Portugal as letras de imprensa, proibindo que

(91). - Afonso Arinos de Melo Franco, Terra do Brasll, Comp. Edit. Nacional, São Paulo 1939, p. 91.

(92). - Roger Picaxd, Le Romantisme Social, Brentano's ed., New York, 1944, p. 282.

(93). - Pedro Herriquez Ureña, Las Corrientes Literarias en la America Hispanica, p. 98.

(94). - Eduardo Frieiro, O Dlabo na Livraria do Cônego, Itatiaia ed.y Belo Horizonte, 1957, pp. 22-37. 
se imprimissem livros, obras ou papéis avulsos e cominando a pena de prisão para o reino" (95).

Fundou ainda D. João VI, as Academias de Marinha e Militar; escolas de cirurgia, no Rio de Janeiro e na Bahia, que se ampliam em 1809 e em 1813 e nas quaisi se origina o ensino médico brasileiro; cursos de economia (1808), de agricultura (1812), de química, geologia e mineralogia (1817) - sendo assim a "obra escolar de D. João VI, impelida pelo cuidado de utilidade prática e imediata... uma ruptura completa com o programa escolástico e literário do período colonial", e, dêste modo, "uma das fases mais importantes de nossa evolução cultural, o período mais fecundo [...] de numerosas instituições nacionais de cultura e de educação" (96) .

Esta obra, inspirada como se vê, no traço imediatista e utilitarista do português e, por certo, adeqüada às exigências e ao desêjo de desenvolver e equipar o país, lembra, como escreve Fernando de Azevedo, a obra escolar da Revolução (97), cujo espírito era - e com razão - anti-universitário. Cogitouse, porém, em 1816, da criação de um Instituto Acadêmico que abrangeria o ensino das ciências e das belas letras, enfim, de algo semelhante a uma Universidade. O projeto dêsse Instituto (para a direção do qual D. João VI chegou a convidar José Bonifácio de Andrada e Silva, que a recusou) gorou e, parece, isso se deveu à tenaz oposição do elemento português, ainda preponderante à roda de D. João VI. No entanto, como escreve Oliveira Lima, "o século XVIII português fôra intelectualmente, de metade brasileiro"... (98) .

Proclamada a Independência, cinco anos depois, em 1827, foram criadas as duas faculdades de direito. Na Constituinte de 1823 , porém, já se voltara a cogitar da criação da Universidade. Fernandes Pinheiro propunha que se fundasse uma em São Paulo e, no projeto de constituição apresentado por José Bonifácio, Antônio Carlos, Araújo Lima e outros, em setembro de 1823 , propunha-se, no seu artigo 250 , a criação de escolas primárias em cada têrmo, ginásios em cada comarca e universidades nos mais apropriados locais (99) .

\footnotetext{
(95). - M. D. Moreira de Azevedo, A Instrução Pública nos Tempos Coloniais do Brasil, in "Revista do Inst. Histórico", vol. LV, 1892, p. 144, apud Fernando de Azevedo, A Cultura Brasileira (3a. edd), t. III, p. 36 .

(96). - Fernando de Azevedo, ob. cit., p. 71.

(97). - Fernando de Azevedo, ob. cit., p. 69.

(98). - Olivelra Lima, D. Joáo vi no Brasil, Tip. do Jornal do Comércio (1a. ed.), Rio de Janeiro, vol. I, 1908, p. 243; Cf. Oliveira Lima, ob. cit., vol. I, pp.' 229 e segs.; Cf. Octavio Tarquínio de Sousa, 'José Bónifácio; José Olímpio ed., Rlo de Janeiro, 1945, p. 92:

(99). - Apud Fernando de Azevedo, ob. cit., p. 73 .
} 
Longo e fastidioso seria comentar tôdas as tentativas que foram feitas para a fundação de uma Universidade no agitado período político pelo qual passou o país, desde a abdicação do primeiro imperador, em 1831, até a pacificação em 1845. Não era êsse tempo por certo propício a tais preocupações. Ainda assim, em 1836 respondendo a sugestões que lhe faziam, dizia - ministro José Inácio Borges, que não julgava judiciosa a organização de uma universidade, pois a experiência mostrara que a "subdivisão de estudo das ciências tem produzido melhores efeitos do que a reunião em um só centro" (100), concepção contrária à idéia de Universidade e que lhe servia para contornar dificuldades políticas que, da criação de um tal instituto, poderiam advir em virtude de ciúmes provinciais (101). Já em 1837, outro ministro afirmava a "absoluta precisão de criar-se uma autoridade individual ou coletiva, a quem se incumba a tarefa de vigiar (?) sôbre as doutrinas ensinadas à mocidade..." (102).

Em 1842 era apresentado outro projeto criando uma Universidade para o "ensino das ciências sociais exatas e naturais" ra capital do Império, extinguindo-se os cursos de direito de São Paulo e de Olinda, assim como os cursos de medicina (103). Novas tentativas seriam feitas até 1870 quando, então, foi apresentado o projeto de reforma de ensino de Paulino de Souza que criava, no Kio de Janeiro, uma Universidade com quatro faculdades: a de direito, de medicina, de ciências naturais e matemáticas e de teologia (104). Foi para essa reforma que João Alfredo solicitou em 1871 , a opinião dos institutos de ensino superior. Na resposta da Congregação da Faculdade de Medicina da Bahia, encontramos esta advertência: a de que era necessária a "criação de escolas profissionais, onde as classes operárias achassem meios de aproveitar a sua natural inclinação; porque só desta forma, teremos artistas dignos de uma nação que procura caminhar nas largas vias do progresso" (105).

Esqueciam os catedráticos que as clásses operárias eram então constituídas por escravos... E que as escolas profissionais nada mais eram, em face das condiçôes econômicas do país, que simples escolas de pequeno artezanato.

Novas tentativas em 1877 e em 1881...

(100). - Primitivo Moacyr, A Instrução e o Império, Comp. Edit. Nacional, São (101). - Primitivo Moacyr, ibidem.

(102). - Primitivo Moacyr, ibidem.

(103). - Primitivo Moacyr, ob. cit., p. 461.

(104). - Prmitivo Moacy, A Instruçáo e o Império, Comp. Edit. Nacional, vol. III, p. 524 - São Paulo, 1938.

(105). - Primitivo Moacyr, ob. cit., (3.0 vol.), p. 530. 
Foi contra o projeto de 1881 - que pretencia criar a Imperial Universidade de D. Pedro II, que se insurgiram os positivistas, considerando-a como uma tentativa absurda, que só serviria para sistematizar, como êles diziam, a nossa pedantocracia (106).

A Universidade era, na opinião dos discípulos brasileiros de Comte, "um atentado à liberdade espiritual" (107).

Eram suficientes no Brasil, afirmavam, as escolas profissionais. A Universidade viria apenas "dar maior intensidade às 'deploráveis pretens̄ões pedantocratas da nossa burguesia, cujos filhos abandonam as demais profissões, igualmente honrosas, para só se preocuparem com a aquisição de um diploma qualquer" (108).

O certo é que, ainda êste projeto, tão do agrado do Imperedor, não vingou. E' possível que a crítica de Teixeira Mendes tivesse contribuído para isso. Creio, todavia, que mais que essa crítica, contribuiu para que não mais se falasse no desejado projeto de Universidade, o desinterêsse de quase todos. Salvo alguns áulicos ou algum idealista impeniente, ninguém estava interessado na Universidade... Nem as verdadeiras condições do meio e da época eram de molde a justificá-la. A Universidade seria algo de estranho, de infecundo - de ornamental e sem significação - naquele ambiente louisphilippard do senhor $D$. Pedro II. Bem mais razoável foi, por certo a criação então da Escola de Minas em Ouro Prêto. O Império passava por uma transformação econômica que o conduziria, em breve, a sua queda. A Universidade naquele momento nada significava para a Nação.

A abolição da escravatura - essa chaga de onde derivaram tantos dos males - arrastaria consigo num grande processo de transformação, que se vinha desenvolvendo desde 1850, o regime monárquico, flor exótica que sempre fôra na América.

A República, impreganada em pequena parte de uma vaga ideologia positiva e espenceriana e, em grande parte, pelo voltairianismo dos conselheiros do Império, logo transformados em

\footnotetext{
(106). - Cf. Cruz Costa, Contribuição à História das Idéjas no Brasil, José olímpio ed., Rio de Janeiro, 1956, p. 203.

(107). - Cruz Costa, fbidem.

(108). - Miguel Lemos, La Circular Anual do Apostolado Positivista do Brastl, p. 97.
} 
bonzos da política do novo regime, também não revelara interêsse pela universidade. Poucas foram as vêzes que surgiram, nos quarenta anos de existência do que chamamos de República Velha, as veleidades de criação do instituto universitário. Surgiram, sim, - novas escolas de engenharia, de direito, de medicina e algumas, menos prestigiosas, de agricultura... A profissionalização do ensino superior era - e ainda é - a regra. Dêsse meio "profissional" destacaram-se às vêzes, alguns matemáticos, naturalistas, filólogos, um Farias Brito, que se obstinou durante tôda sua vida em ser "filósofo"; críticos, como João Ribeiro, bacharel em direito como quase todos; historiadores... Um dos nossos maiores historiadores foi um autodidata: Capistrano de Abreu. Um ou outro intelectual que se afastara da via régia do bacharelismo, ou do exercício da clínica para a pesquisa; um ou outro engenheiro interessado em matemática ou em física; e outros, que haviam realizado estudos na Europa - eram os que sonhavam com a Universidade.

Evidentemente, apenas isso não era suficiente, nem justificava a sua criação.

No entanto, "a transformação do mundo - escrevia em 1942, Mário de Andrade - com o enfraquecimento gradativo dos grandes impérios, com a prática européia de novos ideais políticos, a rapidez dos transportes e mil e uma outras coisas internacionais, bem como o desenvolvimento da consciência americana e brasileira, os progressos da técnica e da educação, impunham a criação, e mesmo a remodelação da inteligência nacional" (109).

O chamado movimento modernista - de renovação da-perspectiva intelectual e artística - coincidiu, em 1922, com a aceleração do processo de transformação política, social e econômica de uma sociedade agrária que, no passado, detivera o latifúndio e o poder, no sentido de uma sociedade industrial, como a que se vinha formando depois da primeira guerra mundial. Como resultado do crack de 1929, tivemos a crise do café, do General Café, acrescida da periódica e perigosa agitação que sempre envolve as sucessões presidenciais. Assim em 1930, a Revolução de Outubro destruiu a primeira República, a que assentava no domínio, mais ou menos pacífico do partido único, constituído dos "partidos republicanos" regionais, regidos pelos "coronéis", dignos herdeiros dos barões do café. Uma nova fase da nossa história aí começava.

(109). - Mário de Andrade, o Movimento Modernista, CES ed., Rio de Janeiro, 1942, p. 13 . 
Tudo isto, é natural, não era suficiente para explicar e de molde a justificar a criação da Universidade e, menos ainda, para remodelar a inteligência brasileira. Mas, nisto tudo, revelava-se a exigência dessa remodelação e, para obtê-la, impunha-se, acreditavam alguns, a criação do instituto universitário. $\mathrm{O}$ ensino superior, porém, continuava dirigido no interêsse da profissão e nada se tentara para que o espírito científico, já existente em alguns institutos de ciência aplicada, se estendesse a domínios mais largos (110). O Professor Claude LeviStrauss, que ensinou na Faculdade de Filosofia, Ciências e Letras da Universidade de São Paulo, em 1935 e 1936, em seu livro Tristes Tropiques (111) diz que, do namôro do velho amigo do Brasil que foi Georges Dumas, com a burguesia brasileira "muito refinada e um pouco decadente", resultou o nascimento da Universidade, pretensa "cobertura ideológica de um parlamentarismo educado" (112).

E' possível que, em parte, o ilustre professor do Colégio de França tenha razão. Mas certo é, também que, para a pequena burguesia - viveiro que é de trabalhadores intelectuais - a Universidade, sobretudo a Faculdade de Filosofia, Ciências e Letras, já se apresentava, há muito, como exigência que se tornaria mais premente depois da Revolução de 1930 e, ainda aí, em virtude de razões ideológicas. Teriam sido, assim, êstes proprietários agrícolas, que deslocavam "progressivamente seus capitais para aplicações industriais, com participação estrangeira", à procura de nova ideologia os interessados na criação da Universidade, na qual supunham ser, com os seus olhos de "liberais" do século XIX, uma fortaleza de seus ultrapassados ideais. Ora, seria precisamente dos rebentos da nova Faculdade "provindos de imigrantes recentes ou de fazendeiros ligados à terra e arruinados pelas flutuações do comércio mundial" (113) que surgiria a revolta contra aqueles "liberais" - os chamados grã-finos - transformados agora, no contraste do tempo e sob a capa de uma curiosa "democracia", em verdadeiros corifeus da reação. A fundação da Faculdade de Filosofia, Ciências e Letras da Universidade de São Paulo iria "permitir a essas classes modestas começar sua ascensão" [...] contribuindo para formar uma nova elite que se entregaria à tarefa de solapar a classe feudal que, como diz ainda o Prof. Levi-Strauss "nos

(110). - Fernando de Azevedo, ob. cit., t. III, pp. 185-186.

(111). - Claude Levi-Strauss,- Tristes Trópicọs (trad. W. Martins), Anhembi ed., São Paulo, 1957.

(112). - Claude Levi-Strauss, ob. cit., p. 13.

(113). - Claude Levi-Strauss, tbidem. 
havia introduzido no Brasil... para servir-lhe em parte de caução e em parte de passatempo" (114).

$\mathrm{O}$ que se remodelara, porém, fôra a própria situação do país, acelerada pelo surto industrial decorrente das condições da vida econômica mundial. Um progresso de consciência se fizera sentir. Mais poderosa, a burguesia, que ora rumava do café para as grandes indústrias; mais consciente a pequena burguesia e procurando arregimentar-se o proletariado, -1930 foi, com as suas contradições, o fim de uma fáse de cultura, como escreve Nelson Werneck Sodré, "a encruzilhada bem viva em que devia esvanecer-se o predomínio de uma elite de puros letrados, de diletantes do conhecimento, de amadorismo vago e dispersivo" (115).

Compreendemos - ou compreenderam alguns - que faltava lastro objetivo, teórico, ao que fazíamos, e que sempre fôra marcado pelo traço do empirismo e da improvisação. Os próprios primeiros resultados da Revolução de Outubro revelariam a nossa incerteza de rumo, o nosso desencôntro de orientações...

E' possível - é bem possível que eu me engane e que aqui faltem, nesta tentativa de interpretação das razões que levaram à criação da Universidade de São Paulo, ou mais exatamente: de sua Faculdade de Filosofia, Ciências e Letras, inúmeros outros dados, alguns talvez imponderáveis (ou quem sabe) ponderáveis demais... Se erro, deixo todavia aqui o meu depoimento, que é precisamente, o de um representante da geração que viveu no anseio de ver criada, em sua terra, uma Universidade como aquelas que eu conhecera na Europa, na minha primeira mocidade. E' verdade que os jovens - e essa experiência, ai de mim! eu a fiz, - não possuem bem exato o sentido das relações... Mas, como dizia Mário de Andrade "acreditar é muitas vêzes um ato de caridade"...

Este mesmo Mário de Andrade dizia, considerando a nova geração universitária, que "sob o ponto de vista cultural progredimos bastante. Se em algumas escolas tradicionais há muito atraso, junto aos núcleos de certas faculdades novas de filosofia, ciências e letras, de medicina, de economia e política, já vão se formando gerações bem mais técnicas e bem mais humanísticas.

(114). - Claude Levi-Strauss, ibidem.

(115). - Nelson Werneck Sodré, Ortentaçōes do Pensamento Brasileiro, Vecch1 ed., Rlo de Janeiro, 1942, p. 14. 
Há um realismo novo, um maior interêsse pela inteligência lógica $[\ldots]$. E esta melhoria sensível de inteligência técnica se manifesta principalmente nas escolas que tiveram o bom senso de buscar professôres estrangeiros, ou mesmo brasileiros educados noutras terras, os quais trouxeram de seus costumes culturais o progresso pedagógico, uma mentalidade mais sadia que desistiu do brilho e da adivinhação" (116).

Nestas palavras de Mário de Andrade, haverá um elogio ou uma terrível crítica? E' o que me pergunto.

\section{$\mathrm{V}$}

Procurei examinar até aqui, o processo histórico da Universidade no Brasil.

Não sei, porém, até que ponto êste processo se assemelhará ao das Universidades latino-americanas de origem espanhola, - as da fachada atlântica, que evolveram em um meio de intensa imigração; as do Pacífico; as do Mar das Caraibas e a do México - que, por certo, às suas semelhanças fundamentais de origem, devem ter juntado outros traços peculiares às condições do meio e às vicissitudes de sua formação nacional.

As Universidades e os Colégios foram, em nosso continente, desde os meados do século XVI até o século XVIII, as grandes sementeiras da cultura européia que recebemos através da Península. Por intermédio de umas e de outros, adquirimos a soma de conhecimentos que constituiam o cabedal de inteligência do Ocidente. E' certo que, umas e outros, foram, no passado, quase sempre, como escrevia Alfonso Reyes, aquela "solene casa sonora", onde se ensinavam e explicavam confusos e densos problemas teológicos, jurídicos e retóricos já resolvidos pela Igreja e acêrca dos quais não habia possibilidade de revisão... (117). Mas foi nessas casas sonoras - perfeitamerite idênticas no espírito às da Metrópole, onde se requintavam finezas - que se fixaram as bases do nosso ensino superior que nem sempre, no decorrer de dois séculos, se revelou apenas naquele humanismo ornamental a que nos referimos, mas que também se manifestou em obras que traduziam curiosidade e interêsse pela nova terra, como, por exemplo, o livro do Pe. José Gumilla, O Orinoco (116). - Mário de Andrade, Aspectos da Literatura Braslleira, Américo-edit., Ro de Janeiro, 1943, p. 238.

(117). - Alfonso Reyes, Letras de la Nueva Ispana, Fondo de Cultura, México, 1948 , p. 35 . 
Ilustrado; o Ensayo sobre la Historia de Chile, de Juan Inacio de Molina; os Tratados da Terra e da Gente do Brasil, de Fernão Cardim e o grande livro de Antonil, Cultura e Opulência do Brasil por suas Drogas e Minas.

Em consonância com o espírito do tempo, frades e jesuítas realizaram o que lhes era possivel realizar, e que só êles poderiam realizar.

No Brasil os jesuítas foram, como já dissemos, os monopolizadores de todo o ensino. Assim, no século XVIII, quando êles já começavam a "cultivar as ciências matemáticas e naturais", superando o humanismo renascentista católico, e procurando modificar o ensino verbalista do passado (118), sua expulsão determinaria, apenas estagnação e desordem no nosso progresso intelectual, pois os que os substituiriam não possuiam, nem as qualidades nem o interêsse, nem a tradição escolar dos Padres. Com a reforma empreendida por Pombal, "aumentava, sem dúvida em várias Capitanias o número de professôres e aulas, mas o progresso do ensino era insignificante" (119) .

$\mathrm{E}$, ainda então, seriam os seminários que continuariam a assegurar o nível médio de cultura do passado.

A partir dos meados do século XVIII, tanto no Brasil como nos demais países da América Latina (é o que verifico nas obras de Jimenez Rueda e de Pedro Henriquez Ureña (120), nossa cultura intelectual toma outro rumo: toma o sentido profissional e técnico, característico do espírito e das idéias do Enciclopedismo, para o qual a missão do homem é conhecer a natureza e dominá-la. A Universidade - e eu acrescento: os colégios dos jesuítas -, como escrevia Martinez Paz, formaram, no entanto, "o cérebro da maioria dos pensadores da Revolução" (121).

O ensino superior colonial - a Universidade fradesca ou o colégio jesuítico - apesar de seus erros e defeitos, foi, pois, transmissor de cultura.

\footnotetext{
(118). - Júlio Jimenez Rueda, Letras Mexicanas en el siglo XIX, Fondo de Cultura, Méxtco, 1944, p. 27.

(119). - Octávio Tarquínio de Sousa, Frades e Professôres, in "O Estado de São Paulo", de 4 de setembro de 1947.

(120). - Júlto Jimenez Rueda, ibldem e Pedro Henriquez Ureña, Fistoría de la Cultura en la América Hispânica, pp. 43-4:

(121). - Apud Alfredo L. Palacios, La Universidade Nueva, Gleizer ed., Buenos Atres, 1925, p. 30:
} 
Não nos deteremos a examinar a lenta evolução do ensino superior profissional e técnico do Brasil no século XIX, que se conservou nos moldes em que o criara D. João VI e que, com o tempo, apenas foi ampliado, refletindo assim o própria lentidão do desenvolvimento econômico, social e político do Império. Reformaram-se as escolas fundadas pelo monarca português, as de medicina e de engenharia; inaugurou-se em 1875 a Escola de Minas de Ouro Prêto.

E' certo que, de 1868 a 1878, novas idéias agitaram - e arejaram - a até então madorrenta atmosfera em que vivera o meio cultural brasileiro. Mas, apesar do positivismo, do espencerismo - talvez de um vago saint-simonismo, assim como das idéias ditas "científicas" de um rídiculo germanismo (e tudo isto era então muito discutido pelas elites de "delgada corteza") - o velho espírito conservador, ainda perdurava, sobretudo nas Faculdades de direito, de onde provinham os bacharéis que dominavam a política do país, por conta dos "barões", proprietários de engenhos e de fazendas de café.

Essas escolas profissionais, e mais particularmente, as $\mathrm{Fa}-$ culdades de Direito, logo se transformariam, na falta de Universidade, em uma espécie de studia generalia (122), precário organismo pré-universitário do Brasil. Depois da metade do século XIX entraria a concorrer com elas a Escola Militar.

"Na classe média nascente é que o Exército vai colher os seus oficiais, alguns vindos de soldados, outros preparados nesse centro de estudo da classe média, que seria, por oposição às faculdades jurídicas da aristocracia agrária, desde 1874, a Escolà Militar" (123).

Euclides da Cunha foi um dos seus alunos, como o seria, mais tarde, Luís Carlos Prestes.

Assim, desde os últimos anos do Império até 1930, a cultura científica e literária brasileira foi assegurada pelos que passaram pelas nossas diversas Faculdades e escolas técnicas. Delas saíram durante mais de um século, os profissionais que constituiriam, até há pouco, a ciência brasileira; alguns dos seus representantes, graças aos institutos que a defesa da saúde, da economia e da agricultura exigia, são nomes que o país hoje respeita e venera. Do jornalismo e de grande número de autodidatas, provinha outra grande parte da elite intelectual brasileira.

Muito mais haveria a dizer - de bem e de mal - sôbre esta profissionalização da cultura e êste autodidatismo, como pou-

(122), - Fernando de Azevedo, A Cultura Brasileira, t. III, p. 91.

(123). - San Tiago Dantas, Dois Momentos de Rui Barbosa, Rio de Janeiro, 1951, p. 18 . 
co há que referir - de mal e de bem - acêrca da Universidade, principalmente sôbre os resultados, ainda em prova, das chamadas Faculdades de Filosofia, como é, por exemplo, a de São Paulo - a mais antiga dentre as novas Faculdades - e cujo $25 .^{\circ}$ aniversário de fundação foi melancòlicamente comemorado a 25 de janeiro de 1959. Mais vale porém que prossigamos...

Ao preparar êstes dados, que me serviriam para as palestras que deveria realizar aqui em Montevidéu, eu relia alguns trabalhos de Carlos Vaz Ferreira. E detive-me então, a pensar em certas semelhanças de situação que se apresentaram em nossos países em relação ao problema universitário. Assim, o que Vaz Ferreira refere em uma das suas conferências, a de 1914, sôbre Enseñanza Superior, retrata o que também se passava em meu país.

A situação do ensino brasileiro era também, como observara Vaz Ferreira para a do Uruguai, de "deficiência" e de "quase inexistência de manifestação de cultura superior" (124).

As faculdades existentes no Brasil até a fundação da Universidade continuavam dirigidas para os interêsses de diferentes profissões e não alagarvam os horizontes da cultura.

Desde 1926, que é de quando data o grande inquérito realizado por Fernando de Azevedo em São Paulo, dizia êste ilustre pensador, verdadeiro forjador da Universidade de São Paulo, que "por mais dura e deprimente que possa parecer a muitos, não é triste dissimular a verdade incontestável de que o ensino superior em São Paulo, como em geral no Brasil, ainda não se despreendeu nem se elevou acima dos limites estreitos de preparação profissional" (125).

Nenhum movimento havia no sentido de se estabelecer a Universidade e, ainda então se discutia acêrca de "sua oportunidade, importância e utilidade"... (126).

Dizia ainda, Fernando de Azevedo - o homem que realizou uma reforma de instrução pública "que se adiantara ao seu respectivo sistema político". (127) - "que as Universidades por tôda a parte constituem núcleos de ação e de orientação, não apenas científicos, mas sociais e políticos, devem ser organiza-

\footnotetext{
(124). - Carlos Vaz Ferreira, Lecciones sobre Pedagogia $y$ Cuestiones de Ensefianza, Montevidéu, 1957, vol. 2, t. XV, pp. 89-90.

(125). - Fernando de Azevedo, A Educação Pública em são Paulo, Companhia Edit. Nacional, São Paulo, 1937, p. 448.

(126). - Fernando de Azevedo, ob. cit., p. 449.

(127). - Gerardo Séguel, La Nueva Educación en el Brasll, in "Revista de Pedagogia", ano $X$, n.o 112, p. 158 .
} 
dos para funcionar como fôrças vivas do país e centros germinadores e orientadores de correntes de opinião" (128).

Como se vê, Fernando de Azevedo visava não apenas constituir um núcleo de investigação científica mas ainda, um centro germinador e orientador de opiniões que traduzissem as fôrças vivas do país.

Mas se difícil era lutar, como escrevia Vaz Ferreira, "contra los practicos, contra los practicos de cierta especie, que abundan en todos los paises y más en los nuestros" (129), êsses existiam também no Brasil... Era mister, pois, para se criar, a Universidade, criar logo, criar "d'emblée", uma faculdade completa que, desde o início, se assemelhasse às faculdades de ciências e letras da tradição universitária européia, e era natural que, em virtude da influência francesa, vigente no Brasil desde o século XVIII, êsse modêlo fôsse o francês.

$\mathrm{E}$ assim essa criação, deve-se à larga visão, à pertinácia e à habilidade de Fernando de Azevedo que, aproveitando - é curioso e paradoxal! - de um momento de exceção, como o interregno revolucionário e ditatorial que se seguiu à Revolução de Outubro de 1930, que se prolongou até 1934 - foi quem tudo planejou para que se fundasse, no Brasil, em 25 de janeiro de 1934, a primeira Faculdade de Filosofia, Ciências e Letras e, com ela, a Universidade de São Paulo, que muito deveu também ao apôio político do Dr. Júlio de Mesquita Filho e do então interventor, Armando de Salles Oliveira.

Não fôssem, o desenvolvimento econômico do Estado de São Paulo, a oportunidade política que, no caso, podemos considerar como feliz e o pensamento de Fernando de Azevedo - viga mestra de nossa Faculdade, no dizer de Antônio Cândido - teria a Universidade existido? E' o que fico muitas vêzes a meditar... Não fôsse tudo isso, a Universidade, instituto de cultura que nos faltava, talvez permanecesse até hoje como sonho de um punhado de intelectuais teóricos (na boa acepção que dá ao têrmo Vaz Ferreira) como os que, desde 1926, desde 1932 (130) lutavam por ela. Não tivesse sido abalado, desarticulado também, em 1930, o domínio econômico dos grupos que regeram a política brasileira durante tôda a primeira fase republicana, o anseio de uma parte da inteligência brasileira, representativa da pequena burguesia e, também.

(128). - Fernando de Azevedo, ob. cit., p. 302.

(129). - Carlos Vaz Ferreira, Sobre la Enseñanza en nuestro país, Montevidéu, 1957, vol. XIII, p. 19.

(130). - Fernando de Azevedo, A Educaçáo entre dois Mundos, Melhoramentos ed., São Paulo, s-d., p. 59 e seg. 
de insignificante parcela dos chamados granfinos - os que julgavam poder encontrar na Universidade "coberta ideológica para um parlamentarismo educado" ou mero "passatempo", - a Universidade talvez não existisse ainda hoje. A cultura brasileira continuaria a ser expressada pelos representantes das profissões "liberais".

Contra os práticos, escrevia Fernando de Azevedo já em 1926:

"A conquista da civilização e dos meios de enriquecê-la, pelas contribuições originais, é vitória dos países que sabem extrair do seio da nação uma elite de homens, utilizada, pela intensidade de culturas sucessivas em tôda extensão de sua capacidade. Não há, porém, sombra de espírito aristocrático, que repugna aliás à nossa educação, quando insistimos na necessidade de se atacar sèriamente o preparo das elites intelectuais. Se há suspeita que não pode ser levantada contra a Rússia de hoje é a de tendências aristocráticas... Pois bem, o govêrno dos Soviets, um dos primeiros problemas que enfrentou, inaugurando a nova organização social e política, foi êsse das Universidades, que, aos olhos da própria ditadura do proletariado, não era menor do que o da educação do povo e encerrava em si a solução de questões de mais vulto e mais urgentes para os interêsses da comunidade e das instituições. Não lhe pareceram suficientes as universidades que existiam; criou mais cinco e reorganizou as outras, para lhes assegurar maior amplitude de ação. Só em nosso liberalismo de epiderme, de uma sensibilidade estranha, e em outros casos tão embotada, chega a provocar pruridos democráticos o contacto com êsse problema da cultura das elites... [...]: Educação popular e preparo das €lites são, em última análise, as duas faces de um, único problema: a formação da cultura nacional" (131).

Assim: educação popular e Universil|dade são as verdadeiras criadoras de cultura.

A Universidade é, pois, criadora de cultura quando não se afasta do povo. E' certo, porém, que não podemos falar numa cultura intelectual exclusivamente nossa, pois vivemos ainda na "franja da cultura européia" (132).

(131). - Fernando de. Azevedo, A Educação Páblica em são Paulo, pp. 452-453. (132). - Herbert W. Schneider, A History of American Philosophy, Columbia University Press, New York, 1947, p. 8 . 
Podemos, todavia, falar de uma experiência americana, argentina, uruguaia, mexicana, chilena, brasileira - como a que se veio formando, lentamente, nestes quatro séculos e meio de uma aventura, por vêzes dramática, da construção de nossa vida histórica, de nossas nações. Temos sido protagonistas talvez um pouco secundários da história durante todo êsse tempo. Falamos português ou espanhol, mas o nosso destino já se desprendeu da Espanha e de Portugal. Não constituimos com êsses países uma só comunidade, pois em nossa formação têm influído outros povos. Hispanidad e lusitanidade não têm aqui maior significação e do próprio panamericanismo temos, muitas vêzes, razão de desconfiar, pois "começa a ser denunciado como justificação camuflada da hegemonia norte-americana" (133).

E' sabido que a civilização e a cultura européias colocadas em face das contingências do meio americano, aceitaram, assimilaram e produziram novas formas de vida, revelando-se até certo ponto criadoras - escreve Sérgio Buarque de Holanda e não sòmente conservadoras de um legado tradicional nascido em clima estranho (134). Assim, cumpre-nos conservar, enriquecendo-o, o precioso legado da cultura intelectual européia. E graças ao nosso desenvolvimento como nações, já estamos a revelar as nossas criações.

Se a cultura, como diz amigo Risieri Frondizi, "não é algo de acabado, de estável, de fixo; material que não se pode alheiar e separar dos que a criaram, dos que vivem dela e nela" (135), se cultura é experiência viva, é ligação com as contingências da existência humana e, ao mesmo tempo, superação dessas contingências concretas pela inteligência; - ela é criação constante, é constante transformação e não estática abstração. Assim, pois, nós, partindo da experiência que é a nossa, também podemos criar e colaborar em um novo humanismo e não apenas nos apresentarmos, na história, como fornecedores de matérias primas...

Uma das características, no entanto, da cultura brasileira, escreve Fernando de Azevedo, "foi e talvez seja o fato de que ela ficou, mesmo no período de seu maior florescimento, confinada à elite, mais larga na república que no império, mais lar-

\footnotetext{
(133). - Cândido Antônio Mendes de Almeida, Perspectiva atual da América Latina, Ministério da Educaçáo e Cultura ed., Rio de Janeiro, 1959, p. 11. (134). - Sérgio Buarque de Holanda, Monçбes, SEB ed., Rlo de Janeiro, 1945, p. 7. (135). - Risieri Frondizi, Raiz Fllosbfica de Males Universit́ários, in "Revista de la Universidad de Buenos Aires’ $V$ epoca, año $I, n .0^{\circ}$, p. 337.
} 
ga hoje do que no primeiro quartel dêste século, mas à qual o povo ou se manteve ausente ou continuava a opor uma resistência passiva. O mal, como querem alguns, não estava nas influências européias ou em quaisquer outras, que tenha sofrido [...], mas nesse fato do alheiamento, maior conforme as épocas, ao seu próprio meio, e do divórcio, em conseqüência entre as elites e o povo" (136).

$O$ analfabetismo, o baixo nível de vida do povo, torna difícil, senão impossível, o bom êxito - e eu diria a própria Universidade. Esta ressente-se sempre da situação em que se encontram as massas. Impõe-se, pois, - e é essa a grande responsabilidade da Universidade latino-americana - tudo fazer para elevar o nível de vida das massas dos nossos países. E' preciso não esquecer que do mesmo modo que "a sociedade produz o homem, é ela produzida por êle".

Não basta, pois, alfabetizar. E' preciso mais.

Não basta ter cultura e afirmar que se ama o povo, e que por isso queremos alfabetizá-lo e elevar-lhe o nível de vida. E' necessário refletir sôbre as próprias condições de nossa cultura e indagar da natureza das razões que lhe dão, talvez, no momento atual, uma certa aparência irrisória e que a tornam ineficaz. E essas razões, são, sem dúvida nenhuma, muito concretas...

São muito concretas, pois, governantes há que não consideram o capital investido na escola - primária, secundária e superior - como a mais lucrativa e perfeita das suas aplicações. Infelizmente, muita gente que governa - ou que pretende governar - faz da política cultural, simples demagogia, como já se viu em meu país.

Se a Universidade quiser subsistir nos nossos países, é mister que se pague bem aos professôres, que se lhes proporcione meios de obter bons laboratórios e bibliotecas. E' mister constituir e pagar bem os professôres primários, os da escola secundária - extensão que é da Universidade, sem o que esta nunca existirá e será apenas privilégio de alguns.

E' necessário, sobretudo, não olvidar os compromissos que, desde o início da nossa história tivemos com o povo que trabalhou para a construção das nossas nações; é mister sentir, clara, a responsabilidade que todos temos em relação à educação pú-

(136). - Fernando de Azevedo, A Educação entre dols Mundos, p. 32. 
blica e popular pois a conquista da América foi, dizia com razão Bernal Diaz, uma emprêsa de caráter popular, na qual a massa desempenhou a parte principal.

E assim, e só assim, a nossa Universidade será criadora de cultura, da cultura de um continente em que se fundem tôdas as raças e tôdas as idéias. 